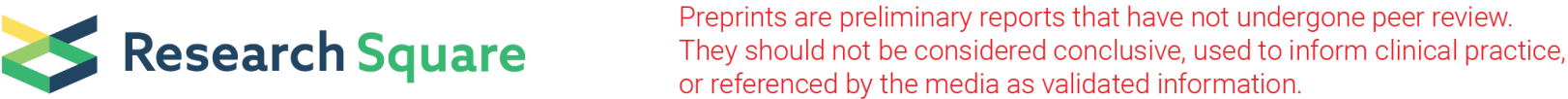

\section{Geochemical characterization of groundwater and water quality assessment for sustainable management of hard rock aquifer in South India}

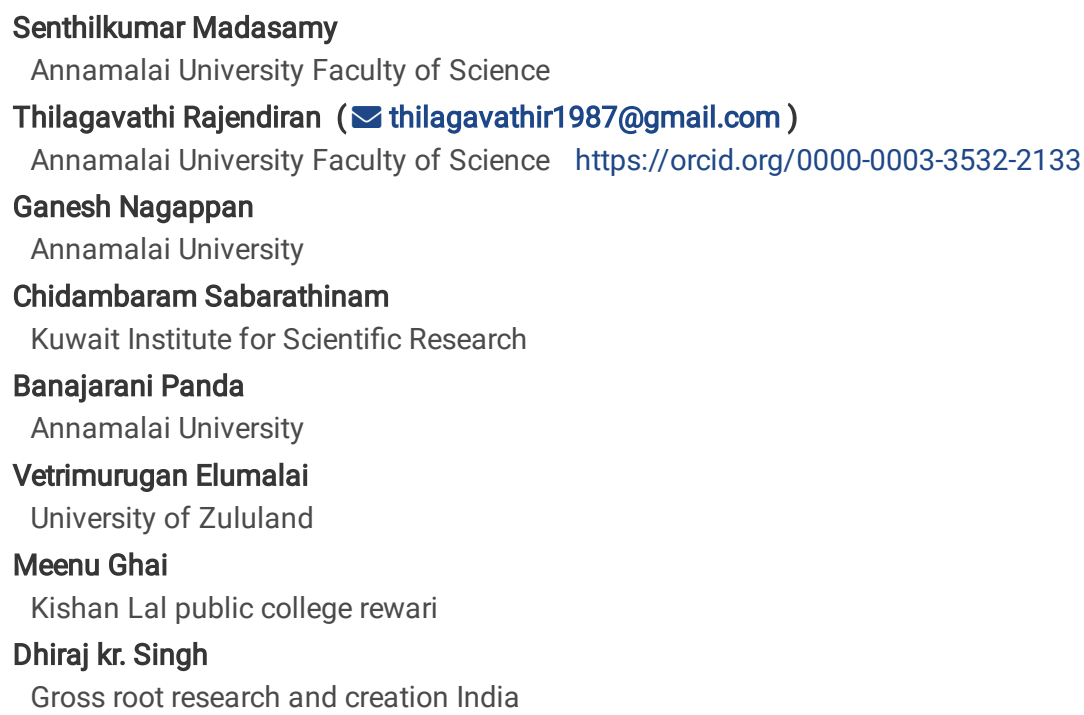




\section{Abstract}

Hydrogeochemical investigation was carried out in groundwater of Virudhunagar district, Tamil Nadu, India. Geologically the study area is occupied with Archaean, Charnockite, Unclassified Genesis and Pleistocene Laterite formations. A total of 72 groundwater samples were collected spatially during North East Monsoon (NEM) in 2019 based upon the coverage of geological formations. The collected samples were studied for different physio-chemical parameters like $\mathrm{pH}$, TDS and $\mathrm{EC}$, major cations ( $\mathrm{Ca}, \mathrm{Mg}, \mathrm{Na}, \mathrm{K})$ and major anions $\left(\mathrm{Cl}_{1} \mathrm{HCO}_{3}, \mathrm{SO}_{4}, \mathrm{PO}_{4}\right)$. EC and TDS ranges from 273 to $5869 \mathrm{mg} / \mathrm{L}$ and 194 to $4159 \mathrm{mg} / \mathrm{L}$. The ionic dominance of the hydrochemical parameters follows in the order of $\mathrm{Na}>\mathrm{Ca}>\mathrm{Mg}>\mathrm{K}$ and $\mathrm{Cl}>\mathrm{HCO}>$ $\mathrm{SO}_{3}>\mathrm{PO}_{4}$. The data represents two major hydrogeochemical facies of $\mathrm{Ca}^{-} \mathrm{HCO}_{3}$ and mixed $\mathrm{Ca}-\mathrm{Mg}-\mathrm{Cl}$ in the study region. The USSL classifications of samples signifies low alkali hazard and high to very high salinity hazard. The higher concentration of TDS and EC in the samples reflects the unsuitability of groundwater. According to the WHO drinking water quality standards and the value of SAR, RSC, Na\% reflects the groundwater in the study region is more suitable for irrigation than drinking purpose. The statistical method also adopted to understand the major factors influencing the variation in hydrochemistry of the region. Weathering, leaching of salts and anthropogenic activities were identified to be the key governing factor in the varied groundwater chemistry of this region.

\section{Introduction}

The quality of water is the dynamic concern for mankind, meanwhile it is openly connected with human welfare. Mostly the groundwater (about 20 to $40 \%$ ) is utilized for the drinking purposes in world (Morris et al. 2003). It is also playing a vital role in the agricultural activities and its development. Increasing the population leads to increasing the need of more groundwater resources for agricultural and every day household needs. Still, maximum of the aquifers is not of sufficiently functioning for good quality water due to the impact of various factors like natural or anthropogenic impact (Epule et al. 2011). Hence, Deprived water quality will distress the human health and also agricultural development (Olajire and Imeokparia 2001), hence it is directly and badly affecting economic growth and social wealth of the country (Milovanovic 2007). The chemical characteristics of groundwater is mainly processed by natural and anthropogenic factors (Garcia et al. 2001; Nur et al. 2011; Fakir et al. 2002; Kim et al. 2005). Recent researchers are more concern on the hydrogeochemical studies (Chidambaram et al. 2011, Thilagavathi et al. 2012, Thilagavathi et al. 2020; Kumaresan and Riyazuddin 2006; Thivya et al. 2013; Adithya et al. 2016 Tatawat and Singh 2008; Panda et al. 2017; Semwal and Jangwan 2009; Dinesh and Singh 2010; Biswajeet and Saied 2011; Senthil et al. 2014; Devaraj et al. 2018). The groundwater quality and its movements is dependent on the properties of nearby lithology and also by the varies activities by the human (Jayaalakshmi et al. 2012). The spatial and sequential assessment of most important ions in groundwater is a broadly recognized tool to afford an imminent around the aquifer's heterogenetic and connectivity, moreover the processes that control the ground water interaction (Panda et al. 2017; Chidambaram et al. 2012).

Ground Water quality and geochemistry plays a significant character in groundwater defense and also quality management. Since, it is most important to assess the quality of groundwater for the present-day and future usage (kori et al.2006). Many researchers have recommended different methodology for analyzing quality of groundwater (Bassam and Rumikhani 2003; Hameed et al. 2010, Selvam 2017, Singaraja et al. 2015). The groundwater quality of Virudhunagar district and its taluks were reported by Nageswari et al. (2007), Magesh et al. (2013) Udayanapillai, et al. (2016), Muthulakshmi et al. $(2009,2010)$, Ponmanickam et al. (2007). The heavy metal level in groundwater and its health hazard were studied by Raja et al. (2021).

Therefore, it is very necessary to evaluate about the current status of groundwater quality and its suitability for drinking and irrigation. Agriculture is a principal practice in the in Virudhunagar, as it is the foremost source of requirements for the majority of the people. The study area also predominantly depends on the agricultural and small to large scale industries of fireworks, printing, ginning factories, Oil and spinning mills, power and hand loom industries and Cement industries. Since it is most significant to study the groundwater quality and the factors governing the hydrochemical variation towards the groundwater resource management. Monitoring of variation in hydrochemical parameters has proved to be advantageous in solving many groundwater quality problems and is being used as a powerful tool by the hydrologists. To derive a proper management strategy a detailed study on the suitability of groundwater for irrigation and also for the drinking purposes and its spatial variation is essential. Hence, present study attempts to evaluate the groundwater suitability for both drinking and irrigation purpose. Also the study describes the processes in control of groundwater geochemistry of this region.

\section{Study Area}

The current study area is positioned in Virudhunagar district, at the Southern part of the Tamilnadu state, India. It covers an area of about 4,234 square kilometers and lies between the latitude $9^{\circ} 24^{\prime} 27.85^{\prime \prime} \mathrm{N}$ to $9^{\circ} 11^{\prime} 10.19^{\prime \prime} \mathrm{N}$ and longitude of $78^{\circ} 24^{\prime} 9.55^{\prime \prime} \mathrm{E}$ to $78^{\circ} 5^{\prime} 24.45^{\prime \prime} \mathrm{E}$ (Fig. 1 ). It is bounded by the Western Ghats in the West, Madurai district in the North, Sivagangi district in North East, Ramanathapuram district in the East and Thothukudi district in the South. Study area comprises eight taluks such as 1. Aruppukkottai, 2. Kariapatti, 3. Srivilliputhur, 4. Rajapalayam, 5. Virudhunagar, 6. Sivakasi, 7. Sattur and 8. Tiruchuli taluks. The total population of the district is about 17,51,301. The Vaippar, The Gundar, and The Arjunanadi are the three major rivers flows in the district and the drainage pattern is dentritic. The climatic condition is generally hot, dry with less humid. The normal yearly rainfall of the study region is $987 \mathrm{~mm}$. The annual temperature is between $23.78^{\circ} \mathrm{C}$ and $33.95^{\circ} \mathrm{C}$ and the temperature rise up to $40.2^{\circ} \mathrm{C}$ during the daytime.

The study region is mostly covered by the physiographic units of plains, uplands, hills and valleys. The landuse of the study area comprise by built-up land, agricultural land, forest, wastelands, and water bodies (Magesh and Chandrasekar 2013). Paddy is the predominant crop type in this area 
followed by the Sugarcane, Groundnut and Pulses are the major cultivation in the study region. Foremost soil types of the study region are Black soil, Red sandy soil and Deep red loam soil. Geologically the Virudhunagar district can be mostly categorized into hard rock and sedimentary formation (alluvium and tertiary) (Fig. 1). The major part of the region covered by a gneissic group of rocks which include feldspathic gneiss, Charnokite follows in the western part of the area around Srivilliputtur. The pink granite occurs south of Watrap and around Mangalam. The eastern part of the region is covered by alluvial formation in Narikudi and Thiruchuli block. Tertiary formation occupies the eastern region covered Narikudi, Thiruchuli and Kariyapatti block. Limestone, Limekanker and Granite are the major minerals occurred in this region (Magesh and Chandrasekar 2013).

The average water level during pre-monsoon is $12 \mathrm{~m}$ below ground level (bgl) and during post monsoon is $8 \mathrm{~m}$ bgl. The groundwater potential varies among the porous and fissured formation. Groundwater in porous formation occurs in phreatic to semiconfined condition with the average thickness of $25 \mathrm{~m}$ bgl. The aquifers in hard crystalline formation are highly heterogeneous in nature with the thickness of 4 to $15 \mathrm{~m}$ bgl in weathered zone and 10 to $15 \mathrm{~m}$ bgl in dug wells. Hard rock in this region yields $40-110 \mathrm{lpm}$ (liters per minute) and sediments well yield 40-150 lpm. Transmissivity and Storability of fractured crystalline formation is about $1-548 \mathrm{~m}^{2} /$ day and $3.41 \times 10^{-5}$ to $7.0 \times 10^{-3}$ and specific yield is about $<2 \%$.

The study area is one of the foremost in overall nation for the match industries, fireworks and printing production, it is generally focused in all over the place of Sivakasi taluk (which is called as small Japan). Virudhunagar district also produce oil, chicory, coffee seeds, dry chillies and pulses. Ginning factories, spinning mills, power and hand loom industries are also existing in the district of Rajapalayam and it is one of the biggest weaving town in all over the state. The cement plants are located in RR Nagar and Alankulam of Virudhunagar and Sivakasi Taluk.

\section{Materials And Methods}

Sampling of Groundwater is carried out during NEM (November 2019). An aggregate of 72 groundwater samples was collected from various hand pumps in different part of the Virudhunagar District. One-liter sample was collected and filtered by using vacuum filtration unit with the Millipore filter paper $(0.45-\mu \mathrm{m})$ to remove the suspended sediments. The collected groundwater samples were analyzed for physical parameters (EC, pH, TDS), using the field wings multi-parameter (PCSTestr ${ }^{\mathrm{TM}}$ 35). The major cations like $\mathrm{Ca}$ and $\mathrm{Mg}$ were determined by titration method. Na and $\mathrm{K}$ were analysed using Flame photometer (CL 378). Similarly, anions like $\mathrm{Cl}$ and $\mathrm{HCO}_{3}$ was analysed by titration, $\mathrm{SO}_{4}, \mathrm{PO}_{4}$, and $\mathrm{SiO}_{2}$ were analyzed by using spectrophotometer (UV $1800 \mathrm{spec}$ ). The different analyses were carried out by following the standard procedures (APHA, 1998). At the time of sampling the water temperature varies between 26 and $32^{\circ} \mathrm{C}$. The analytical accuracy for the results of cations and anions was measured by computing the ionic balance represents about 5-10\% (Freeze and cherry, 1979). The data produced to find the quality index to calculate Sodium absorption ratio (SAR), Sodium Percentage (Na\%), Residual sodium Carbonate (RSC), Magnesium Hazard (MH), Kelly Ratio (KR) (Table 1) and USSL were plotted using CHIDAM software. Spatial diagram was plotted using ArcGIS. The multivariate analysis was adopted to categorized the chemical and physical variables of big data by using (SPSS) version 17.0.

\section{Result And Discussion}

The analytical outcomes suggest the physicochemical parameters and its maximum, minimum and average value for the groundwater samples are represented in Table 2 and 3 respectively. The values of hydrochemical parameters were compared with the WHO standard (2014). Based on average value of the parameters the dominance of major cations is arranged in the order of $\mathrm{Na}>\mathrm{Ca}>\mathrm{Mg}>\mathrm{K}$ and anions are $\mathrm{Cl}>\mathrm{HCO}_{3}>\mathrm{SO}_{4}>\mathrm{PO}_{4}$.

\section{Suitability of drinking water quality:}

The $\mathrm{pH}$ values in the groundwater samples ranges between 6.75 and 8.38 , indicating the nature of groundwater is alkaline and it is due to the existence of carbonic acid which is produced by the $\mathrm{CO}_{2}$ and $\mathrm{HCO}_{3}$ in water and it affects the level of $\mathrm{pH}$ in the groundwater (Azeez et al 2000; Ramesh and Elango, 2012). The basicity is also due to the limestone rock dissolution and limestone mining (Essumang et al,2011; Marzouk 2018) and the pH level is within the acceptable limits of the WHO standards. Spatially most of the higher pH sample with alkaline nature is observed in the Eastern and North western part of the study region which is occupied by the geology of Alluvium and Feldspathic Gneiss (Fig 2).

The Electrical Conductivity (EC) and Total Dissolved Solids (TDS) of groundwater is directly related to level of dissolved salt in groundwater. The EC value of the samples varies from 273 to $5870 \mu \mathrm{m} / \mathrm{cm}$ with an average value of $1593 \mu \mathrm{m} / \mathrm{cm}$ (Fig. 3). About $36 \%$ of samples are above the permissible limit of WHO standards (Table 3). Total Dissolved solids (TDS) value in the groundwater samples are ranging between 194 and 4160 mg/I (Table 2 ). The maximum value of EC and TDS is observed at Sattur followed by the Virudunagar, Varagnur and Velanoorni. The great difference in EC is mostly related to the lithological composition, dissolution of salts as an outcome of limestone quarrying undertakings (Prowse 1987; Eugene et al. 2014) and other anthropogenic activities like waste outlet from the small and large firework, cement, ginning factories in Sattur and Virudhunagar and dumping of manure beside the riverbeds is predominant in the study region. The lower level of EC is due to lesser groundwater residence time in the aquifer and also by the less dilution process (Kortatsi 2006; Chidambaram et al. 2011; Thivya et al. 2013). The higher values of EC are observed in central, east and southern part of the study region (Fig 3).

The analytical data represents the Calcium and Magnesium concentration varies from 20 to $892 \mathrm{mg} / \mathrm{L}$ and 4.8 to $450 \mathrm{mg} / \mathrm{L}$. Samples of about $22 \%$ to $11 \%$ are above the permissible limit of WHO standards (Table 2 and 3 ). The higher concentration of Ca which is in the not permissible category is observed in isolated patches near North, South east and South west part of the study region (Fig 4). Maximum value of Mg is noted in Eastern, 
Northern and Southern part of the study area (Fig 4). Since the higher concentration of $\mathrm{Ca}$ and $\mathrm{Mg}$ in groundwater is due to the dissolution of limestone, granulite and other alkaline metamorphic rocks weathering (Chandrasekhar et al. 2012; Ayyandurai et al. 2011; Udayanapillai and Kaliammal, 2016; Marzouk 2018). Maximum value of Ca and Mg is noted at Varagnur and Virudhunagar locations.

Both Sodium and Potassium concentration ranges from 9 to $944 \mathrm{mg} / \mathrm{L}, 3$ to $296 \mathrm{mg} / \mathrm{L}$ respectively. 24\% and 17\% of groundwater samples higher than the WHO standard for Na and K respectively (Table 3). Higher concentration of $\mathrm{Na}$ is observed as an isolated patch in northern, eastern and southern part of the study region. Southern and south eastern part of the region shows high concentration of $\mathrm{K}$. Higher concentration of Na and $\mathrm{K}$ (Fig 5 ) is observed at Virudunagar, Varagnur, Muthaneri, Velanoorni and Panaiyur locations. Weathering of minerals are the major source of higher level of Sodium and Potassium in groundwater of the study region (Udayanapillai and Kaliammal 2016). The study area is mostly occupied by the Feldspathic Gneiss. Wells closer to the quarries are also shows increasing level of $\mathrm{K}$ in groundwater which infiltrates the pollutants in the groundwater (Marzouk, 2018).

The maximum and minimum concentration of $\mathrm{Cl}, \mathrm{HCO}_{3}, \mathrm{PO}_{4}$ and $\mathrm{SO}_{4}$ ranges from 53 to $2980 \mathrm{mg} / \mathrm{L}, 134$ to $1198 \mathrm{mg} / \mathrm{L}, 5$ to $23 \mathrm{mg} / \mathrm{L}$ and 4 to $35 \mathrm{mg} / \mathrm{L}$ respectively. $19 \%$ and $35 \%$ of total samples have $\mathrm{Cl}$ and $\mathrm{HCO}_{3}$ concentration above the permissible limit of WHO drinking water standards (Table 3 \& Fig 6). $\mathrm{PO}_{4}$ and $\mathrm{SO}_{4}$ concentration for all the groundwater samples are within the permissible limit (Fig 7). Higher level of $\mathrm{Cl}$ is observed at Northern, Eastern and southern region of the study area (Fig 6). Maximum of $\mathrm{HCO}_{3}$ (Fig 6) is noted at Sattur, Annikuttam and Mil Krishnapuram locations. Spatially most of the region showed not permissible zone of $\mathrm{HCO}_{3}$ (Fig 6). Anthropogenic waste like agricultural fertilizers, animal waste, municipal and small- and large-scale crackers industries sewage that infiltrates into groundwater leads to the higher concentration of $\mathrm{Cl}$ (Thilagavathi et al. 2014; Thivya et al.2013) and the black soil in the region may also the source for higher Cl (Udayanapillai and Kaliammal 2016). The silicate minerals weathering and also the dissolution of the minerals enriches the $\mathrm{HCO}_{3}$ level in groundwater (Gastmans et al.2010; Khashogji and El Maghraby 2013)

The water quality map was prepared for the parameters of $\mathrm{Ca}, \mathrm{Mg}, \mathrm{Na}, \mathrm{K}, \mathrm{Cl}, \mathrm{HCO}_{3}$, and $\mathrm{SO}_{4}$. These parameters were divided into two (1 and 0 ) based on the WHO drinking quality index. The individual maps for all these 7 parameters were integrated in the ArcGIS platform to plot the final water quality map. Later the total of 7 maps were prepared and categorized into four classes as Excellent, Moderate, Poor and Unsuitable. The final water quality map shows that most of the groundwater samples are falling in Excellent and Good category. Isolated patches of the samples from north, south and east represents the poor and unsuitable category for drinking water (Fig 8). Unsuitable area of groundwater is mainly due to the industrial effluents in the north and southern part of the region and agriculture used fertilizers in the eastern part. The higher level of TDS, Na and $\mathrm{Cl}$ in the study region lead to the unsuitable of ground water quality.

According to the Richards (1954), TDS classification represents that $62 \%$ of samples are below the $1000 \mathrm{mg} / \mathrm{L}$ and useful for the drinking purposes. However, $8 \%$ of samples falls in hazardous category and not useful for the drinking and irrigation purpose. Based on the Total hardness all the groundwater samples fall under the moderately to very hard category (Table 4). More hardness of groundwater is owing to the availability of alkaline earth like $\mathrm{Ca}$ and $\mathrm{Mg}$ which is mostly from the geogenic source and dissolution of composed rocks like limestone and dolomite (Chaudhary et al. 2018).

\section{Suitability of Irrigation quality:}

The groudwater suitability for irrigation purpose is studied from Sodium adsorbtion ratio (SAR) and salinity ratio. The SAR and EC values variation (Chidambaram et al.2020) has been identified from the USSL plot. High level of SAR, reflects the vulnerability of sodium replacing Calcium and Magnesium into the soil and affects its permeability, fertility of the soil and reduce the agricultural activities (Tahmasebi et al.2018).

All the samples falls in the category of good to excellent based on their SAR value (Fig 9) which reprsents the irrigation water are with low sodium hazard. Groundwater with less sodium can be utilized for agriculture (Jeon et al. 2020). The wilcox plot shows that $21 \%$ of samples have low sodium and are falling in medium salinity hazard field of S1-C2 followed by $33 \%$ of groundwater samples with higher salinity and falling in low sodium hazard of S1-C3 category. 21\% of samples are falling in S1- C4 class of low sodium hazard and very high salinity hazard. Based on the wilcox classifiation all the samples have medium to very high salinity with low sodium hazards which signifies that maximum of the samples are appropriate for irrigation purposes of high salt tolerant crops (Zhu 2002). Higher salinity water for the agriculture leads to the salt accumalation in the root and make destruction the plant and lead to drought plant situation (Greenway and Munns 1980; Zhu 2002)

The $\mathrm{Na} \%$ is also assisted to evaluate the suitability of groundwater for irrigation purpose. From Table 4 it is evident that the order of dominance of $\mathrm{Na} \%$ in groundwater samples are Excellent (43\%) > Good (38\%) > Permissible (15\%) > Doubtful (3\%) $>$ Unsuitable (1\%). Samples from Mennakualm,Thamaraiklam and Sattur are not sutiable for the irriagtion. Dissolution and weathering of various minerals and usage of highly chemical fertilizer leads to high $\mathrm{Na} \%$ (Rao 2002; Bhat 2016). Most of the samples are represented in permissible to excellent category point toward the suitablity of groundwater for irrigation (Table 4).

The Residual Sodium Carbonate (RSC) is the sum of excess $\mathrm{CO}_{3}$ and $\mathrm{HCO}_{3}$ over the sum of $\mathrm{Ca}$ and $\mathrm{Mg}$ influences the irrigation quality of water (Eaton,1950) and (Richards, 1954). Table 4 shows that $80.5 \%$ of samples are suitable for agriculture purpose, $8 \%$ of samples are represented in moderate category and $11 \%$ of groundwater samples are not safe for agriculture purpose. The regular use of the higher RSC groundwatre for the 
agriculture purposes leads to decreasing the permeability of soil and blazing of the plants and less yield of the crops (Toumi et al.2015; Ramesh and Elango 2012).

Increasing level of $\mathrm{Ca}$ and $\mathrm{Mg}$ in the groundwater will increase the level of $\mathrm{pH}$ in soil and reduces the inflitration quality of the soil which is directly affects the crop growth.The Magnesium adsorption ratio (Lloyd and Heathcoat 1985) calculated for the study area's groundwater samples representing $58 \%$ of samples are unsafe for the irriagtion and $42 \%$ of sample are in safe category (Table 4 ).

Estimation of irrigation suitability of the groundwater samples proposed by Kelley (1940) and Paliwal (1967) is depends on the Ca and Mg with Na value. The Kelly ratio of $<1$ are not usitable for the irragation. About $91 \%$ of samples are in safe zone for irrgaition and remainning $9 \%$ of samples are in unsafe zone for the groundwater samples. About $39 \%$ of samples are fresh, $17 \%$ of samples are Fresh brackish, $36 \%$ of samples are Brackish and $8 \%$ of samples are from Brackish salt category based on Cl classification (Table 4). Long residene time and antropogenic pollutants infiltration (Subba Rao et al. 2007) are the main source for higher chloride level in the groundwater samples of the study area.

\section{Hydrogeochemical evaluation from Piper diagram:}

Hydrogeochemical facies shows the processes of chemical behavior of the groundwater samples. Based on the cation triangle majority of the samples represent the dominance of Ca-Mg type and few of the groundwater shows the dominance of Na+K type. $40 \%$ of samples fall in CalciumMagnesium facies and $60 \%$ of samples are in Calcium-Sodium Facies (Table 4). According to the anionic triangle all the samples show the predominance of $\mathrm{HCO}_{3}$ and $\mathrm{Cl}$. Chloride-sulfate and Bicarbonate facies is represented by $92 \%$ of samples and $8 \%$ of samples are from Chloride facies. In the diamond field represents the abundance of the water type in the study area is in the order of $\mathrm{Ca}-\mathrm{HCO}{ }_{3}>$ mixed $\mathrm{Ca}-\mathrm{Mg}-\mathrm{Cl}>\mathrm{Ca}-\mathrm{Cl}>\mathrm{Ca}-\mathrm{Na}-\mathrm{HCO}{ }_{3}>$ $\mathrm{Na}-\mathrm{Cl}$ (Fig 10). 49\% of samples falls in $\mathrm{Ca}^{-} \mathrm{HCO}_{3}$ facies representing recharge zone and mainly influenced by the rock water interaction processes (Bricker et al 2003; Devaraj et al. 2018). Followed by that $32 \%$ of samples represented in mixed Ca-Mg-Cl and $8.3 \%$ of samples in Ca-Cl facies indicating the transition zone and influenced by irrigation process due to agricultural activities and other anthropogenic fractors like quarries and crackers industries (Thilagavathi et al.2016; Devaraj et al. 2018). 8\% samples shows the $\mathrm{Ca}-\mathrm{Na}-\mathrm{HCO}_{3}$ facies and $2.7 \%$ of samples represented in Na$\mathrm{Cl}$ field indicating the dissolution and anthropogenic impact (Krishnakumar et al.2016). The chemical constutients of the samples is predominantly influneced by the the dissolution and also precipitation of minerals during groundwater recharge.

\section{Gibb's Hydrogeochmical evaluation:}

Gibbs plots is used to demonstrate the ratio between the cation and anion along with TDS to categorize the process liable for the variation in groundwater chemistry. Based on the Gibbs diagram (Fig 11) maximum of the samples are influenced by rock-water interaction which signifying the influence of local geological sources, weathering of minerals. However few samples shows the dominance of the manmade activities (Chidambaram et al.2008; Manikandan et al.2011). Samples with higher TDS values, and $\mathrm{Na} /(\mathrm{Na}+\mathrm{Ca})$ and $\mathrm{Cl} /\left(\mathrm{Cl}+\mathrm{HCO}_{3}\right)$ ratio signifies control of evaporation . It specifies that the evaporation-sedimentation is the main factor of the variation in chemical composition of groundwater of the study area (Udayanapillai and Kaliammal 2016).

\section{Correlation matrix:}

The correlation matrix of the samples represents both positive and negative co-relationship between the variables (Thivya et al.2015). A strong postive correlation (>0.5) noted between $\mathrm{Cl}-\mathrm{Ca}, \mathrm{Mg}, \mathrm{Na} ; \mathrm{Ca}-\mathrm{Mg}, \mathrm{K}, \mathrm{Cl} ; \mathrm{Mg}-\mathrm{Na}, \mathrm{Cl}, \mathrm{HCO}$; $\mathrm{Na}-\mathrm{Cl}, \mathrm{HCO}$. A strong correlation between EC and TDS with $\mathrm{Ca}, \mathrm{Mg}, \mathrm{Na}, \mathrm{Cl}$ and $\mathrm{HCO}_{3}$ (Table 5). Positive and good correlation of $\mathrm{Cl}$ with other parameters indicates the impact of anthropogenic activities and ion exchange process (Thilagavathi et al. 2012; Thivya et al.2013;). $\mathrm{HCO}_{3}$ with $\mathrm{Ca}$, $\mathrm{Na}$ and $\mathrm{Mg}$ reflects the weathering of limestone in the study region (Marzouk 2018). Good correlation of $\mathrm{EC}$ with other parameter indicates that the $\mathrm{Ca}, \mathrm{Mg}, \mathrm{Na}, \mathrm{Cl}$ and $\mathrm{HCO}_{3}$ are the substantial ions for higher $\mathrm{EC}$ in groundwater of the study area.

\section{Factor analysis:}

Factor analysis is a multivariate arithmetic technique, offers the overall connection among the measured chemical variables by displaying the multivariate patterns that could help to categorize the original data (Table 6). The factor analysis has generated three significant factors with the total variance of $70.3 \%$. Factor I, represents $38.6 \%$ of total variance with a strong positive loading of $\mathrm{Mg}, \mathrm{Na}, \mathrm{Cl}_{1} \mathrm{HCO}_{3}, \mathrm{EC}$ and TDS, in the study area demonstrating the leaching of secondary salts, and anthropogenic activities (Prasanna et al. 2010, Thivya et al.2013; Devaraj et al.2016). About 23\% of the groundwater samples in the study area obtained from the Factor 1, spatially most of the positive loading samples of factor I represented on isolated patches of North east, western and southern part of the study area (Fig 12). Factor II shows strong representation of Ca, Mg, $\mathrm{K}, \mathrm{Cl}$ with a negative loading of $\mathrm{pH}$ with total variance of $20.6 \%$ and $33 \%$ of samples represents in this factor II. Dominance of $\mathrm{Ca}$ and $\mathrm{Cl}$ indicates the influence of anthropogenic activities in limestone quarries and other industries like cement factories, paper plants and crackers industries. Positive loading of Mg and $\mathrm{K}$ with negative $\mathrm{pH}$ represents the ion exchange leads to the rock water relations and also the weathering activities (Chidambaram et al. 2007). Positive score of Factor II represented in the western and south western part of the study region (Fig 12). Factor III elucidates $11 \%$ of total variance and $35 \%$ of samples. This factor shows the positive loading of $\mathrm{SO}_{4}$ and $\mathrm{PO}_{4}$ which may be influenced from anthropogenic impacts like agriculture (fertilizer) activities (Vengosh and Keren 1996). Most of the Western and isolated patches of the eastern and northern part of the study area shows the dominance of the factor III (Fig 12). Comparing the percentage of samples with positive loading shows that Factor III shows $35 \%$, factor II obtained 
$33 \%$ and Factor I obtained $23 \%$ of samples signifying dominance of anthropogenic activities to the variation in groundwater chemistry of the study area.

\section{Conclusion}

Sodium and Calcium are the principal cation and Chloride and Bicarbonate are the dominant anions in the groundwater of the study area. Groundwater samples of the study area are mostly alkaline with the higher TDS and EC due to the varied lithology and intense industrial and agriculture activities. $22 \%, 11 \%, 24 \%, 17 \%, 19 \%$ and $35 \%$, of samples are directly above the acceptable limit for $\mathrm{Ca}, \mathrm{Mg}, \mathrm{Na}, \mathrm{K} \mathrm{Cl}$ and $\mathrm{HCO}$ respectively. The increasing trend of the concentration of the hydrochemical parameters in groundwater are mostly due to dissolution of minerals and intensive anthropogenic activities (both industrial and agricultural activities). The USSL classification for TDS reveals that $62 \%$ of the samples are within good category and useful for drinking purpose. It is inferred from the water quality map shows that isolated patches from north, south central and eastern parts are representing poor to unsuitable category of drinking water Groundwater samples from Virudhunagar, Vadamalapuram, Varaganur, Idayakulam, Sattur, Menakulam, Muthaneri, Velanoorani and Tuttinattam represents the poor to unsuitable category, due to the impact of industries and limestone queries nearby locations. SAR of all the samples represent good to excellent category. RSC, MH, KR and Na\% exposes that greater than $80 \%$ of samples are suitable for irrigation. Gibbs diagram shows the major controlling factor area evaporation and rock water interaction. Piper diagram represents the dominance of the $\mathrm{Ca}_{-}-\mathrm{HCO}_{3}$ and mixed $\mathrm{Ca}-\mathrm{Mg}-\mathrm{Cl}$ water type. Leaching of salts, weathering and influence of manmade activities are foremost factors influencing the groundwater chemistry of the study area. Thus, it is inferred from the study that the groundwater is appropriate for irrigation and drinking purposes except certain places in north, south and eastern part of the study region.

\section{Declarations}

Acknowledgment: The author Mr. M. Senthilkumar, wish to express his thanks to Department of Science \& Technology (DST), India, for providing the necessary financial support to carry out this study vide reference No: GUCC /DST PURSE II/Manpower /1028/2019, dated 19.08.2019. The authors from AU express their gratitude to the University of Zululand and Annamalai University for the MoU, which has paved way for this collaborative work, towards analysis and interpretation of results.

Funding information: This study was financially supported by the Department of Science \& Technology (DST), No: GUCC /DST PURSE II/Manpower /1028/2019, dated 19.08.2019.

Conflict of interest: On behalf of all authors, the corresponding author states that there is no conflict of interest.

Research involving Human Participants and/or Animals: This article does not contain any studies involving animals and human participants performed by any of the authors.

Authors' contribution statements: All authors listed on the title page have contributed significantly to the work, have read the manuscript, attest to the validity and legitimacy of the data and its interpretation, and agree to its submission

Ethics Data Availability: The manuscript, Data are the authors' original work and the manuscript has not received prior publication and is not under consideration for publication elsewhere. The manuscript now submitted is not copied or plagiarized version of some other published work.

Declaration: Authors declared that the manuscript should not be submitted for publication in any other Journal or Magazine till the decision is made by journal editors.

\section{References}

Abdul Hameed M, Jawad Alobaidy, Mukheled A, Al-Sameraiy, Abass J, Kadhem, Athmar Abdul Majeed (2010) Evaluation of Treated Municipal Wastewater Quality for Irrigation. Journal of Environmental Protection 1:216-225. https://doi.org /104236/jep

Adithya V S, Chidambaram S, Thivya C, Thilagavathi R, Prasann M V, Nepolian M, Ganesh N ( 2016) A study on the impact of weathering in groundwater chemistry of a hard rock aquifer. Arab J Geosci 9: 158. https://doi.org /101007/s12517-015-2073-3

APHA (1998) Standard methods for the examination of water wastewater 19th edition Apha Washington DC

Ayyurai R, Suresh M, Venkateswaran S (2011) Evaluation of Groundwater for Irrigational Purposes in Cumbum Valley Theni District Tamilnadu India, International Journal of Innovative Technology Exploring Engineering 2 :182-185

Azeez PA (2000) Ecological implications of surface irrigation In Environmental awareness on quality management of irrigation water. Eds Lakshmanaperumalaswamy P, Krishnaraj P, 14-25, Bharathiar University Public Works Department Tamil Nadu India

Bhat MA, Grewal MS, Ramprakash R, Wani SA, Dar EA (2016) Assessment of Groundwater Quality for Irrigation Purposes using Chemical Indices. Indian Journal of Ecology 43: 574-579

Page 6/23 
Biswajeet Pradhan, Saied Pirasteh (2011) Hydro-Chemical Analysis of the Ground Water of the Basaltic CatchmentsUpper Bhatsai Region Maharastra. The Open Hydrology Journal https://doi.org /102174/1874378101105010051

Bricker O P, Jones B F, Bowser C J (2003) Mass-balance Approach to Interpreting Weathering Reactions in Watershed Systems. Treatise on Geochemistry 119-132. https://doi.org /101016/b0-08-043751-6/05180-x

Chaudhary V, Satheeshkumar S (2018) Assessment of groundwater quality for drinking irrigation purposes in arid areas of Rajasthan India. Applied Water Science 8: 218 https://doiorg/101007/s13201-018-0865-9

Chidambaram S, Karmegam U, Prasanna MV (2011) A study on hydrochemical elucidation of coastal groundwater in around Kalpakkam region Southern India. Environment Earth Science 64: 1419-1431.https://doi.org/101007/s12665-011-0966-3

Chidambaram S, Harish Bhary, Khaled Hadi (2029) A software for Chemical Interpretation of the Dissolved ions in Aqueous Media Groundwater for sustainable development. CHIDAM https://doi.org/101016/jgsd2020100496

Chidambaram S, VijayakumarV, Srinivasamoorthy K, Andhan P, PrasannaM V, Vasudevan S (2007) A study on variation in ionic composition of aqueous system in different lithounits around Perambalur region Tamil Nadu. Journal of Geological Society of India 6:1061-1069

Chidambaram S, Ramanathan AL, Prasanna MV, Andhan P, Srinivasamoorthy K, Vasudevan S (2020) Identification of Hydrogeochemically Active Regimes in Groundwaters of Erode District Tamilnadu. A Statistical Approach Research Article Asian Journal of Water Environment Pollution 5: 93102

ChidambaramS, Karmegam U, Prasanna MV (2011) A study on hydrochemical elucidation of coastal groundwater in around Kalpakkam region Southern India. Environ Earth Science 64: 1419-1431. https://doi.org/101007/s12665-011-0966-3

Chra Sekhar Reddy L, Deshpe SM, Ramana Reddy KV, Aher KR (2012) Hydro Geochemical Processes in the Groundwater Environment of Vemula area Kadapa District South India. International Journal of Recent Trends in Science Technology I3:18-24 ISSN 2277-2812 E-ISSN 2249-8109

David Essumang K, Senu J, Fianko, Nyarko J R , Adokoh KCK, Boamponsem L (2011) Groundwater Quality Assessment A physicochemical properties of drinking water in a rural setting of developing countries. Canadian Journal on Scientific and Industrial Research 2

Devaraj N, Chidambaram S, Pa B (2018) Geo-electrical approach to determine the lithological contact groundwater quality along the KT boundary of Tamilnadu India. Model Earth System Environment 4: 269-27. https://doi.org/101007/s40808-018-0424-2

Dinesh Kumar Tank, Singh Chel CP (2010) A hydrochemical elucidation of the groundwater composition under domestic irrigated in Jaipur City. Environmental Monitoring Assessment 166: 69-77. https://doi.org 101007/s10661-009-0985-7

Eaton FM (1950) Significance of Carbonates in Irrigation Waters. Soil Science 69:123-134 https://doi.org/101097/00010694-195002000-00004

Epule E T, Peng C, Lepage L, Chen Z, Forest Loss Triggers in Cameroon (2011) A Quantitative Assessment Using Multiple Linear Regression Approach. Journal of Geography Geology. https://doi.org /105539/jggv3n1p30

EugeneLamare R, Shylla R, Sing OP (2014) Assessment of ground water quality from dug wells in west Jaintia hills district Meghalaya India. International jouranal of environement science 3. https://doi.org /106088/ijes2014050100048

Fakir Y, Mernissi MEl, Kreuser T, Berjami B (2002) Natural tracer approach to characterize ground water in the coastal Sahel of Oualidia Morocco. Environmental Geology 43:197-202. https://doi.org/ 101007/s00254-002-0644-6

Freeze R A, Cherry J A (1979) Groundwater,Prentice Hall, Englewood, Cliffs, New Jersey,pp 604.

Garcia AM, Vieira J P, Winemiller KO (2001) Dynamics of the shallow-water fish assemblage of the Patos estuary Brazil during cold Warm ENSO episodes. Journal of Fish Biology 5:1218-1238

Gastmans D, Chang HK, Hutcheon I (2010) Groundwater geochemical evolution in the northern portion of the guarani aquifer system Brazil its relationship to diagenetic features. Appl Geochem 25: 16-33

Greenway H, Rana Munns (1980) Mechanisms of Salt Tolerance in Nonhalophytes. Ann Rey Plant Physiol 31: 149-159

Jayalakshmi Devi Oinam, Ramanathan, Gurmeet Singh AL (2012) Geochemical statistical evaluation of groundwater in Imphal Thoubal district of Manipur India. Journal of Asian Earth Science 48: 136-149. https://doi.org/101016/ jseaes201111017

Jeon C, Maimoona Raza, Jin-Yong Lee, Heejung Kim, Chang-Seong Kim Bora Kim, Jeong-Woo Kim, Rak-Hyeon Kim Sun-Woo Lee (2020) Country wide Groundwater Quality Trend Suitability for Use in Key Sectors of Korea. Water12:1193. https://doi.org/103390/w12041193

Page $7 / 23$ 
Khashogji MS, El Maghraby MMS (2013) Evaluation of groundwater resources for drinking agricultural purposes, Abar Al Mashi area south Al Madinah Al Munawarah CitySaudi Arabi Arab J Geoscience 6:3929-3942. https://doi.org/101007/s125 7-012-0649-8

Kim HC, Yu MJ (2005) Characterization of natural organic matter in conventional water treatment processes for selection of treatment processes focused on DBPs control. Water Research 39:4779-4789. https://doi.org/101016/jwatres200509021

Kori-Siakpere O JEG, Ake UM (2006) Avworo Sub lethal Effects of Cadmium on Some Selected Haematological Parameters of Heteroclarias A Hybrid of Heterobranchus bidorsalis Clarias gariepinus

Kortatsi BK (2006) Hydrochemical characterization of groundwater in the Accra plains of Ghana. Environmental Geology 50:299-311.

https://doi.org/101007/s00254-006-0206-4

Krishna Kumar S, Hari Babu S, Eswar Rao P, Selvakumar S, Thivya C, Muralidharan S, JeyabalG(2016) Evaluation of water quality hydrogeochemistry of surface groundwater Tiruvallur District Tamil Nadu India. Applied Water Science https://doi.org/101007/s13201-016-04477

Kumaresan M, Riyazuddin P (2006) Major ion chemistry of environmental samples around sub-urban of Chennai city.Current Science 91 : $1668-1677$

Lloyd JW, Heathcoat JA (1985) Natural Inorganic Hydrochemistry in Relation to Groundwater. Oxford University Press

Magesh NS, Chrasekar N (2011) Evaluation of spatial variations in groundwater quality by WQI GIS techniquea case study of Virudunagar District Tamil Nadu India. Arabian Journal of Geosciences6: 1883-1898. https://doi.org/101007/s12517-011-0496-z

Magesh NS, Chrasekhar N, Krishna Kumar S, Glory M, (2013) Trace element contamination in the estuarine sediments along Tuticorin Coast-Gulf of Mannar southeast coast of India. MarinePollutionBulletion 73: 355-361. https://doiorg/101016/jmarpolbul201305041

Manikan S, Chidambaram S, Prasanna MV, Thivya C, Karmegam U (2011) Hydrochemical Characteristics Groundwater Quality Assessment in Krishnagiri District Tamilnadu India. Curtin Sarawak Faculty Office 04. ISSN 0974-5904

Marzouk (2018) Influences of limestone stone quarries on groundwater quality. International Journal of Human Capital in Urban Management https://doiorg/1022034/IJHCUM20180405

Milovanovic M (2007) Water quality assessment determination of pollution sources along the Axios Vardar River. Southeast Europe Desalination 213:159-173 https://doiorg/101016/jdesal200606022

Morris BL, Lawrence ARL, Chilton PJC, Adams B, Calow RC, Klinck (2003) A Groundwater its susceptibility to degradation a global assessment of the problem options for management. Naturalenvironmentresearchcouncil http://wwwuneporg/dewa/Portals/67/pdf/Groundwater

Muthulakshmi L, Anbu Ramu, Kannan N (2009) Physico- chemical characteristics of groundwater in around sivakasi region A statistical approach. Indian Journal of Environmental Health 52:229-234

Muthulakshmi L, Anbu Ramu, Kannan N, (2010) Assessment of groundwater quality virudhunagar district india A statistical approach. Indian Journal of Environmental Health 52: 229-234

Nageswari (2007) Evaluation of groundwater suitability for irrigated_agriculture in Virudhunagar District.Tamil Nadu India Published thesis http://hdlhlenet/10603/115819

Nur A, Ayuni KN (2001) Hydrogeo-physical study of Michika environs northeast Nigeria. International Journal of the Physical Sciences 6: 7816-7827

Olajire AA, Imeokparia FE (2001) Water Quality Assessment of Osun River Studies on Inorganic Nutrients. Environmental Monittoring Assessment 69 :17-28 https://doi.org/101023/A:1010796410829

Paliwal KV (1967) Effect of Gypsum Application on the Quality of Irrigation Waters the Madras Agricultural Journal 59 :646-647

Panda B, Chidambaram S, Thilagavathi R, Thivya C, Ganesh N, Devraj N (2017) Geochemical signatures of groundwater along mountain front riparian zone of Courtallam TamilNadu. Groundwater for Sustainable Development 372-386.http://dxdo.iorg/101016/jgsd201710003

Pearce Kelley C (1940) Former Occupation of small scale http: doi:org/101177/0022224294000500104

Ponmanickam P, Rajagopal K, Rajan MK, Achiraman S, Palanivelu K (2007) Assessment of drinking water quality of vembakottai reservoir virudhunagar district Tamilnadu. Journal expzoo india10: 485-488. ISSN 0972-0030

Prasanna MV, Chidambaram S, Srinivasamoorthy K (2010) Statistical analysis of the hydrogeochemical evoluation of groundwater in the hard sedimentary aquifier system of gadilam river basin South India. Journal of kind Saud University http:doi.org/101016/jjksus201004001 
Prowse CW (1987) The impact of urbanization on major ion flux through catchments A case study in SouthernEngl.WaterAirSoilPollution 32: 277292. https://doi.org/101007/BF00225114

Raja V, Lakshmi RM, Puthiya Sekar C, Chidambaram S, Neelakantan MA (2021) Health Risk Assessment of Heavy Metals in Groundwater of Industrial Township Virudhunagar Tamil Nadu India. Archives of Environmental Contamination Toxicology 80:144-163. https://doi.org/101007/s00244-02000795-y

Ramesh K, Elango L (2021) Groundwater quality its suitability for domestic agricultural use in Tondiar river basin, Tamil Nadu India. Environmental Monittoring Assessment 184: 3887-3899. https://doi.org/101007/s10661-011-2231-3

Rao NS, Rao JP, Devadas DJ, Rao KS, Krishna C (2002) Hydro geochemistry groundwater quality in a developing urban environment of a semi-arid regionGuntur hra Pradesh.Journal of the Geological Society of India 59: 159-166

Richards LA (1954) Diagnosis improvement of saline alkali soils USDA hand book 60 Government Printing Office, Washington, DC, 160

Ronald Gibbs J (1070) Mechanisam Controlling World Water Chemistry.American Association for the advancement of Science 170: 1088-1091

Selvam S, Venkatramanan S, Sivasubramanian P, Chung SY, Singaraja C (2017) Geochemical Characteristics Evaluation of Minor Trace Elements Pollution in Groundwater of Tuticorin City Tamil Nadu India using Geospatial Techniques. journal geological society of india 90: 62-68

Semwal N, Jangwan S (2009) Major ion chemistry of river bhagirathi river kosi in the uttarakh Himalaya. Int J Chem Sci7: 607-616

Senthil Kumar GR, Shankar K (2014) Assessment of Groundwater Potential Zones Using GIS. wwwfgorg @ American V-King Scientific Publishing 2: 110

Senthilkumar M, Elango L (2013) Geochemical processes controlling the groundwater quality in lower Palar river basin southern India. Journal of Earth System Science 122:419-432. https://doi.org/101007/s12040-013-0284-0

Singaraja C, Chidambaram S, Srinivasamoorthy K, Anadhan P, Selvam S (2015) A Study on Assessment of Credible Sources of Heavy Metal Pollution Vulnerability in Groundwater of Thoothukudi DistrictsTamilnadu India. Water Quality Expoure Health 7: 459-467.https://doi.org/101007/s12403-0150162

Subbarao G, Sahrawat V, Berry KL, Nakahara WL, Ishikawa K, Watanabe T, Suenga Y, Rondan K, Rao M (2006) Scope Strategies for Regulation of Nitrification in Agricultural System-Challenge Opportunities. Critical Reviews in plant Science https:// doi.org/101080/07352680600794232

Tahmasebi P, Mahmudy-Gharaie MH, Ghassemzadeh F, Karouyeh AK (2018) Assessment of groundwater suitability for irrigation in a gold mine surrounding area NE Iran Environ Earth Science 677-766. https:// doi:org/ 101007/s12665-018-7941-1

Tatawat RK, Chel CPS (2008) A hydrochemical profileforassessing the groundwater quality of Jaipur City. Environmental Monitoring Assessment 143:337-343. https://doi.org/101007/s10661-007-6-3

Thilagavathi R, Chidambaram S, Prasanna M V, Thivya C, Singaraja C (2012) A study on groundwater geochemistry water quality in layered aquifers system of Pondicherry region southeast India. Applied Water Science 253-269 https://doi.org /101007/s13201-012-0045-2

Thilagavathi R, Chidambaram S, Thivya C, Pethaperumal S, Tirumalesh K, Prasanna M V (2016) Application of Statistical Techniques to Identify the Hydrogeochemical Processes in Coastal Aquifers of Pondicherry Region Tamil Nadu. Geostatistical Geospatial Approaches for the Characterization of Natural Resources in the Environment 251 https://doi.org 101007/978-3-319-18663-4_39

Thilagavathi R, Chidambaram S, Thivya C, Banjarani panda, Ganesh N (2020) Assessment of sources distribution metals in groundwater of Pondicherry regionindia. International Journal of Civil Enviornment Agricultural Engineering 2:33-53

Thilagavathi R, Chidambaram S, Thivya C, Prasanna MV, Singaraja C, Tirumalesh K, Pethaperumal S (2014) Delineation of Natural Anthropogenic Process Controlling Hydrogeochemistry of Layered Aquifer Sequence Proceedings of the National Academy of Sciences India Section. A Physical Sciences 84:95- https://doi.org /101007/s40010-013-0114-4

Thivya C Chidambaram S Singaraja C Thilagavathi R Prasanna MV Anadhan P, Jainab I (2013) A study on the significance of lithology in groundwater quality of Madurai district Tamil Nadu India Environment Development Sustainability Vol15no5pp1365-1387 doi 101007/s10668-013-9439-z

Thivya C, Chidambaram S, Thilagavathi R, Prasanna MV, Singaraja C, Adthiya VS, Nepolian M (2015) A multivariate statistical approach to identify the spatio-temporal variation of geochemical process in a hard rock aquifer .Environmental Monittoring Assessment 187 https://doi.org/101007/s10661015-4738-5

Toumi A, Leteneur S, Gillet C, Debril J F, Decoufour N, Barbier FJ akobi JM (2015) Emiliem Simoneau-Buessinger Enhanced precision of ankle torque measure with an open-unit dynamometer mounted with a 3D force-torque sensor. European Journal of Applied Physiology 115: 2303-2310

Page $9 / 23$ 
https://doi.org/101007/s00421-015-3210-0

Udayanapillai AV, Kaliammal M (2016) Groundwater Characterization Quality Assessment by using GIS Geo Statistics from Palgudi Region Virudhunagar District Tamilnadu India. International Journal of Research in Environmental Science 2:1-16 ISSN 2454-9444 http:/dxdoi.org/1020431/2454-94440204001

Vengosh A, Keren R, (1996) Chemical modifications of groundwater contaminated by recharge of treated sewage effluent.Journal of Contaminant Hydrology23:347-360 http:/dxdoi.org /101016/0169-7722 (96)00019-8

World Health Organization (WHO) (2014) Guidelines for drinking water quality recommendations. http:// wwwwhoint/entity/water_sanitation_health/dwq/

Zhu H, Pan S, Gu S, Bradbury EM, Chen X (2002) Amino acid residue specific stable isotop labeling for quantitative proteomics Rapid Communication in mass spectrometry16: 2115-2123 http:/dxdoi.org 101002/rcm831

\section{Tables}

Table. 1 Chemical, analytical and data calculated methods for groundwater samples-

\begin{tabular}{|c|c|}
\hline Parameters & Method and Materials \\
\hline $\mathrm{pH}$ & \multirow[t]{3}{*}{ multi-parameter (PCSTestr ${ }^{\mathrm{TM}} 35$ ). } \\
\hline $\mathrm{EC} \mu \mathrm{S} / \mathrm{cm}$ & \\
\hline TDS (mg/L) & \\
\hline $\mathrm{Ca}(\mathrm{mg} / \mathrm{L})$ & \multirow[t]{4}{*}{ Titrimetric using Burette, Flasks } \\
\hline $\mathrm{Mg}(\mathrm{mg} / \mathrm{L})$ & \\
\hline $\mathrm{Cl}(\mathrm{mg} / \mathrm{L})$ & \\
\hline $\mathrm{HCO}_{3}(\mathrm{mg} / \mathrm{L})$ & \\
\hline $\mathrm{SO}_{4}(\mathrm{mg} / \mathrm{L})$ & \multirow[t]{3}{*}{ Spectrophotometer/ HACH (DR 6000) } \\
\hline $\mathrm{PO}_{4}(\mathrm{mg} / \mathrm{L})$ & \\
\hline $\mathrm{H}_{4} \mathrm{SiO}_{4}(\mathrm{mg} / \mathrm{L})$ & \\
\hline $\mathrm{Na}$ and $\mathrm{K}(\mathrm{mg} / \mathrm{L})$ & Flame photometer/ Elico CL 378 \\
\hline Sodium Adsorption Ratio (SAR) (meq) & $\mathrm{Na} /(\sqrt{ } \mathrm{Ca}+\mathrm{Mg} / 2)$ \\
\hline Residual Sodium Carbonate (RSC) (meq) & $\left(\mathrm{CO}_{3}+\mathrm{HCO}_{3}\right)-(\mathrm{Ca}+\mathrm{Mg})$ \\
\hline (Sodium percentage) $\mathrm{Na} \%$ (meq) & $\mathrm{Na}+\mathrm{K} /(\mathrm{Ca}+\mathrm{Mg}+\mathrm{Na}+\mathrm{K}) \mathrm{X} 100$ \\
\hline Magnesium Hazard (MH) (meq) & $\mathrm{Mg} / \mathrm{Ca}+\mathrm{Mg} * 100$ \\
\hline Kelly Ratio (KR) (meq) & $\mathrm{Na} / \mathrm{Ca}+\mathrm{Mg}) * 100$ \\
\hline
\end{tabular}

Table. 2 Chemical Composition of groundwater Samples (All Values in $\mathrm{mg} / \mathrm{l}$ except $\mathrm{pH}$ and $\mathrm{EC}(\mu \mathrm{s} / \mathrm{cm}$ ) 


\begin{tabular}{|c|c|c|c|c|c|c|c|c|c|c|c|c|c|c|c|c|}
\hline $\begin{array}{l}\text { ample } \\
\text { imber }\end{array}$ & Location Name & Longitude & Latitude & $\mathrm{Ca}$ & $\mathbf{M g}$ & $\mathrm{Na}$ & $\mathbf{K}$ & $\mathrm{Cl}$ & HCO3 & PO4 & SO4 & SIO2 & $\mathrm{pH}$ & EC & TDS & $\begin{array}{c}\text { Ionic } \\
\text { Balance }\end{array}$ \\
\hline 1 & V.Puthur & $78^{\circ} 22^{\prime} 9^{\prime \prime}$ & $9^{\circ} 35^{\prime} 31^{\prime \prime}$ & 44.0 & 45.6 & 129.0 & 5.5 & 195.0 & 512.4 & 5.5 & 18.1 & 39.0 & 7.6 & 1070.0 & 750.0 & 10.0 \\
\hline 2 & Mennakulam & $78^{\circ} 20^{\prime} 56^{\prime \prime}$ & $9^{\circ} 29^{\prime} 19^{\prime \prime}$ & 20.0 & 34.0 & 399.3 & 3.6 & 326.8 & 1009.8 & 9.5 & 8.6 & 55.2 & 7.8 & 2680.0 & 1890.0 & 10.0 \\
\hline 3 & Irunchirai & $78^{\circ} 20^{\prime} 17^{\prime \prime}$ & $9^{\circ} 38^{\prime} 10^{\prime \prime}$ & 42.0 & 34.4 & 148.5 & 4.0 & 141.8 & 549.0 & 5.7 & 6.8 & 39.9 & 8.1 & 808.0 & 570.0 & 7.3 \\
\hline 4 & Tachanental & $78^{\circ} 13^{\prime} 28^{\prime \prime}$ & $9^{\circ} 43^{\prime} 43^{\prime \prime}$ & 40.0 & 19.2 & 39.8 & 3.4 & 124.1 & 134.2 & 14.1 & 4.2 & 64.7 & 7.9 & 342.0 & 242.0 & 7.1 \\
\hline 5 & Cinimatai & $78^{\circ} 17^{\prime} 32^{\prime \prime}$ & $9^{\circ} 39^{\prime} 3^{\prime \prime}$ & 72.0 & 64.8 & 160.1 & 5.3 & 390.0 & 512.4 & 5.7 & 3.7 & 39.1 & 7.6 & 1130.0 & 799.0 & 10.0 \\
\hline 6 & Narikudi & $78^{\circ} 7^{\prime} 36^{\prime \prime}$ & $9^{\circ} 35^{\prime} 37^{\prime \prime}$ & 160.0 & 141.6 & 239.7 & 4.0 & 709.0 & 634.4 & 5.7 & 10.5 & 50.8 & 7.3 & 2560.0 & 1800.0 & 0.8 \\
\hline 7 & Muthaneri & $78^{\circ} 17^{\prime} 59^{\prime \prime}$ & $9^{\circ} 31^{\prime} 55^{\prime \prime}$ & 316.0 & 292.8 & 203.5 & 10.3 & 1187.6 & 536.8 & 6.1 & 7.2 & 58.8 & 7.4 & 3400.0 & 2390.0 & -7.2 \\
\hline 8 & Velanoorni & $78^{\circ} 4^{\prime} 27^{\prime \prime}$ & $9^{\circ} 27^{\prime} 59^{\prime \prime}$ & 348.0 & 338.4 & 452.3 & 23.4 & 1664.8 & 622.2 & 5.7 & 5.8 & 37.3 & 8.2 & 4610.0 & 3260.0 & -6.8 \\
\hline 9 & Sengulam & $78^{\circ} 17^{\prime} 32^{\prime \prime}$ & $9^{\circ} 19^{\prime} 51^{\prime \prime}$ & 396.0 & 136.8 & 49.6 & 22.6 & 755.8 & 366.0 & 10.1 & 7.4 & 54.1 & 6.9 & 2080.0 & 1450.0 & -9.9 \\
\hline 10 & Tuttinattam & $78^{\circ} 16^{\prime} 33^{\prime \prime}$ & $9^{\circ} 19^{\prime} 50^{\prime \prime}$ & 512.0 & 62.4 & 269.7 & 14.3 & 1097.2 & 353.8 & 5.9 & 10.9 & 62.3 & 7.3 & 3520.0 & 2470.0 & -7.1 \\
\hline 11 & Therkunatham & $78^{\circ} 16^{\prime} 0^{\prime \prime}$ & $9^{\circ} 20^{\prime} 22^{\prime \prime}$ & 104.0 & 45.6 & 17.9 & 20.1 & 124.1 & 280.6 & 5.7 & 11.4 & 62.5 & 7.1 & 420.0 & 275.0 & -9.4 \\
\hline 12 & Suthamadam & $78^{\circ} 12^{\prime} 49^{\prime \prime}$ & $9^{\circ} 21^{\prime} 6^{\prime \prime}$ & 200.0 & 103.2 & 81.0 & 5.2 & 501.3 & 353.8 & 6.9 & 9.6 & 56.6 & 7.1 & 1541.0 & 1100.0 & -4.4 \\
\hline 13 & Kathalampatti & $78^{\circ} 11^{\prime} 31^{\prime \prime}$ & $9^{\circ} 26^{\prime} 27^{\prime \prime}$ & 52.0 & 44.0 & 79.7 & 3.9 & 141.8 & 463.6 & 6.0 & 7.9 & 58.2 & 7.7 & 790.0 & 560.0 & 9.8 \\
\hline 14 & Panaiyur & $78^{\circ} 13^{\prime} 46^{\prime \prime}$ & $9^{\circ} 30^{\prime} 34^{\prime \prime}$ & 224.0 & 230.4 & 405.5 & 4.7 & 1169.9 & 695.4 & 6.0 & 5.5 & 48.5 & 6.9 & 4130.0 & 2930.0 & -3.7 \\
\hline 15 & Tiruchuli & $78^{\circ} 12^{\prime} 22^{\prime \prime}$ & $9^{\circ} 32^{\prime} 2^{\prime \prime}$ & 28.0 & 46.4 & 110.0 & 3.4 & 70.9 & 561.2 & 5.8 & 8.7 & 64.1 & 7.9 & 865.0 & 614.0 & 6.6 \\
\hline 16 & Tamaraikulam & $78^{\circ} 11^{\prime} 43^{\prime \prime}$ & $9^{\circ} 40^{\prime} 11^{\prime \prime}$ & 38.0 & 99.8 & 596.3 & 5.8 & 963.5 & 1012.2 & 7.0 & 8.6 & 64.6 & 7.9 & 4350.0 & 3310.0 & 9.8 \\
\hline 17 & Chokkandal & $78^{\circ} 14^{\prime} 21^{\prime \prime}$ & $9^{\circ} 40^{\prime} 11^{\prime \prime}$ & 96.0 & 38.4 & 53.1 & 3.1 & 106.4 & 500.2 & 5.8 & 15.2 & 33.8 & 7.6 & 686.0 & 483.0 & 6.0 \\
\hline 18 & Avarankulam & $78^{\circ} 13^{\prime} 28^{\prime \prime}$ & $9^{\circ} 42^{\prime} 9^{\prime \prime}$ & 52.0 & 40.8 & 18.8 & 3.4 & 124.1 & 158.6 & 6.5 & 7.4 & 79.1 & 7.1 & 423.0 & 301.0 & -3.3 \\
\hline 19 & Naganathal & $78^{\circ} 6^{\prime} 35^{\prime \prime}$ & $9^{\circ} 43^{\prime} 31^{\prime \prime}$ & 124.0 & 64.8 & 56.8 & 4.3 & 195.0 & 463.6 & 6.3 & 15.4 & 64.6 & 7.2 & 997.0 & 702.0 & -2.0 \\
\hline 20 & Kariyapatti & $78^{\circ} 6^{\prime} 10^{\prime \prime}$ & $9^{\circ} 41^{\prime} 8^{\prime \prime}$ & 68.0 & 52.8 & 77.3 & 4.8 & 106.4 & 585.6 & 6.4 & 5.8 & 53.6 & 7.4 & 885.0 & 630.0 & 6.8 \\
\hline 21 & Srirampoor & $78^{\circ} 10^{\prime} 6^{\prime \prime}$ & $9^{\circ} 39^{\prime} 43^{\prime \prime}$ & 60.0 & 64.8 & 141.3 & 5.0 & 195.0 & 683.2 & 7.1 & 6.9 & 22.2 & 8.4 & 1106.0 & 784.0 & 7.6 \\
\hline 22 & Namasivayapuram & $78^{\circ} 10^{\prime} 6^{\prime \prime}$ & $9^{\circ} 39^{\prime} 43^{\prime \prime}$ & 52.0 & 28.8 & 9.6 & 4.2 & 70.9 & 219.6 & 5.9 & 7.1 & 9.9 & 8.1 & 273.0 & 194.0 & 3.6 \\
\hline 23 & Aruppukkottai & $78^{\circ} 6^{\prime} 8^{\prime \prime}$ & $9^{\circ} 30^{\prime} 23^{\prime \prime}$ & 124.0 & 55.2 & 101.7 & 12.2 & 230.4 & 463.6 & 5.9 & 8.9 & 48.3 & 8.2 & 1215.0 & 858.0 & -3.5 \\
\hline 24 & Savaspuram & $78^{\circ} 7^{\prime} 16^{\prime \prime}$ & $9^{\circ} 30^{\prime} 2^{\prime \prime}$ & 156.0 & 50.4 & 31.6 & 4.7 & 159.5 & 475.8 & 6.1 & 13.5 & 59.5 & 8.3 & 901.0 & 636.0 & -2.7 \\
\hline 25 & Muthuramalinga & $78^{\circ} 9^{\prime} 33^{\prime \prime}$ & $9^{\circ} 27^{\prime} 1 "$ & 20.0 & 33.6 & 108.2 & 4.3 & 53.2 & 500.2 & 6.1 & 9.8 & 40.3 & 8.4 & 663.0 & 474.0 & 8.0 \\
\hline 26 & Ramachandrap & $78^{\circ} 8^{\prime} 17^{\prime \prime}$ & $9^{\circ} 22^{\prime} 38^{\prime \prime}$ & 76.0 & 60.0 & 85.1 & 3.7 & 70.9 & 622.2 & 6.0 & 7.5 & 46.3 & 7.2 & 762.0 & 533.0 & -0.2 \\
\hline 27 & Kosukondu & $78^{\circ} 2^{\prime} 29^{\prime \prime}$ & $9^{\circ} 21^{\prime} 37^{\prime \prime}$ & 32.0 & 33.6 & 63.7 & 3.5 & 70.9 & 353.8 & 7.4 & 14.9 & 50.5 & 7.9 & 506.0 & 362.0 & 7.0 \\
\hline 28 & Kurundhamadam & $78^{\circ} 2^{\prime} 26^{\prime \prime}$ & $9^{\circ} 25^{\prime} 47^{\prime \prime}$ & 72.0 & 52.8 & 9.1 & 2.8 & 70.9 & 341.6 & 6.0 & 5.7 & 32.0 & 7.4 & 435.0 & 308.0 & -3.4 \\
\hline 29 & Ramalingapuram & $77^{\circ} 5951^{\prime \prime}$ & $9^{\circ} 31^{\prime} 14^{\prime \prime}$ & 68.0 & 50.4 & 10.1 & 4.2 & 53.2 & 292.8 & 6.2 & 9.2 & 36.2 & 7.7 & 375.0 & 266.0 & -9.8 \\
\hline 30 & Mallankinru & $78^{\circ} 1^{\prime} 10^{\prime \prime}$ & $9^{\circ} 34^{\prime} 59^{\prime \prime}$ & 48.0 & 67.2 & 92.2 & 3.5 & 53.2 & 573.4 & 6.1 & 9.2 & 48.2 & 7.8 & 785.0 & 560.0 & -3.5 \\
\hline 31 & Vadagarai & $78^{\circ} 4^{\prime} 47^{\prime \prime}$ & $9^{\circ} 38^{\prime} 52^{\prime \prime}$ & 80.0 & 129.6 & 214.3 & 3.4 & 283.6 & 768.6 & 6.0 & 18.6 & 45.1 & 7.5 & 1380.0 & 1944.0 & -6.7 \\
\hline 32 & D.kadampankulam & $78^{\circ} 5^{\prime} 1^{\prime \prime}$ & $9^{\circ} 44^{\prime} 0^{\prime \prime}$ & 260.0 & 81.6 & 95.7 & 7.5 & 496.3 & 488.0 & 6.2 & 9.9 & 34.2 & 6.9 & 1766.0 & 1280.0 & -3.7 \\
\hline 33 & Virudhunagar & $77^{\circ} 56^{\prime} 43^{\prime \prime}$ & $9^{\circ} 35^{\prime} 2^{\prime \prime}$ & 816.0 & 450.4 & 944.4 & 4.0 & 2980.2 & 780.8 & 5.9 & 23.7 & 49.4 & 6.8 & 5670.0 & 3950.0 & -10.1 \\
\hline 34 & Kuppampatti & $77^{\circ} 57^{\prime} 47^{\prime \prime}$ & $9^{\circ} 29^{\prime} 4^{\prime \prime}$ & 32.0 & 86.4 & 20.5 & 3.4 & 106.4 & 317.2 & 6.0 & 18.2 & 50.7 & 7.7 & 684.0 & 403.0 & -5.4 \\
\hline 35 & Appayyanayakk & $77^{\circ} 59^{\prime} 30^{\prime \prime}$ & $9^{\circ} 25^{\prime} 10^{\prime \prime}$ & 156.0 & 40.8 & 13.4 & 3.2 & 190.9 & 378.2 & 5.9 & 17.7 & 41.5 & 7.1 & 706.0 & 500.0 & 1.2 \\
\hline 36 & Maniyampatti & $77^{\circ} 57^{\prime} 51^{\prime \prime}$ & $9^{\circ} 24^{\prime} 14^{\prime \prime}$ & 56.0 & 60.0 & 77.8 & 3.4 & 70.9 & 524.6 & 6.4 & 24.1 & 41.8 & 7.5 & 731.0 & 526.0 & 0.2 \\
\hline 37 & Subramaniyapuram & $77^{\circ} 56^{\prime} 27^{\prime \prime}$ & $9^{\circ} 16^{\prime} 49^{\prime \prime}$ & 88.0 & 67.2 & 144.5 & 4.9 & 90.9 & 627.0 & 6.3 & 31.1 & 58.2 & 7.9 & 1466.0 & 1040.0 & -9.0 \\
\hline 38 & Thottailovanpatti & $77^{\circ} 53^{\prime} 40^{\prime \prime}$ & $9^{\circ} 12^{\prime} 42^{\prime \prime}$ & 352.0 & 98.4 & 109.5 & 18.3 & 744.5 & 414.8 & 9.0 & 32.7 & 53.8 & 6.9 & 2520.0 & 1780.0 & -3.8 \\
\hline 39 & Subbiyapuram.N & $77^{\circ} 53^{\prime} 40^{\prime \prime}$ & $9^{\circ} 15^{\prime} 44^{\prime \prime}$ & 88.0 & 86.4 & 48.0 & 4.7 & 88.6 & 493.6 & 6.3 & 32.5 & 50.8 & 7.5 & 790.0 & 565.0 & -9.2 \\
\hline 40 & Sattur & $77^{\circ} 54^{\prime} 56^{\prime \prime}$ & $9^{\circ} 21^{\prime} 21^{\prime \prime}$ & 68.0 & 120.0 & 903.2 & 3.6 & 833.1 & 1198.0 & 6.5 & 23.6 & 84.2 & 7.7 & 5870.0 & 4160.0 & -9.2 \\
\hline 41 & Vadamalapuram & $77^{\circ} 52^{\prime} 43^{\prime \prime}$ & $9^{\circ} 22^{\prime} 2^{\prime \prime}$ & 40.0 & 40.8 & 47.6 & 3.6 & 53.2 & 402.6 & 6.7 & 29.8 & 64.9 & 7.6 & 485.0 & 344.0 & 8.3 \\
\hline 42 & E.Kumaralingapuram & $77^{\circ} 54^{\prime} 8^{\prime \prime}$ & $9^{\circ} 25^{\prime} 44^{\prime \prime}$ & 104.0 & 129.6 & 310.5 & 3.9 & 619.1 & 768.6 & 6.1 & 26.9 & 61.2 & 7.4 & 2800.0 & 1960.0 & 2.0 \\
\hline 43 & Kattanur & $77^{\circ} 53^{\prime} 39^{\prime \prime}$ & $9^{\circ} 30^{\prime} 43^{\prime \prime}$ & 200.0 & 81.6 & 72.8 & 14.1 & 336.8 & 500.2 & 6.2 & 30.1 & 72.1 & 7.3 & 1340.0 & 940.0 & -4.6 \\
\hline 44 & Kumaraling & $77^{\circ} 55^{\prime} 18^{\prime \prime}$ & $9^{\circ} 34^{\prime} 50^{\prime \prime}$ & 116.0 & 148.8 & 327.5 & 3.8 & 514.0 & 695.4 & 7.0 & 29.1 & 64.6 & 7.8 & 2500.0 & 1780.0 & -9.8 \\
\hline 45 & Puthukottai & $77^{\circ} 45^{\prime} 48^{\prime \prime}$ & $9^{\circ} 35^{\prime} 13^{\prime \prime}$ & 220.0 & 136.8 & 118.0 & 5.1 & 514.0 & 414.8 & 6.9 & 31.5 & 31.7 & 7.6 & 1380.0 & 978.0 & -11.0 \\
\hline 46 & Sukravarapatti & $77^{\circ} 47^{\prime} 57^{\prime \prime}$ & $9^{\circ} 30^{\prime} 54^{\prime \prime}$ & 100.0 & 163.2 & 261.7 & 5.2 & 478.6 & 719.8 & 7.0 & 26.4 & 64.0 & 7.8 & 1732.0 & 1200.0 & -7.2 \\
\hline 47 & Sivakasi & $77^{\circ} 48^{\prime} 0^{\prime \prime}$ & $9^{\circ} 27^{\prime} 36^{\prime \prime}$ & 216.0 & 86.4 & 100.6 & 6.4 & 383.6 & 512.4 & 6.8 & 27.2 & 53.4 & 7.0 & 1167.0 & 803.0 & -5.9 \\
\hline 48 & Anaikuttam & $77^{\circ} 48^{\prime} 52^{\prime \prime}$ & $9^{\circ} 24^{\prime} 27^{\prime \prime}$ & 264.0 & 192.0 & 233.6 & 76.5 & 673.6 & 854.0 & 22.7 & 26.7 & 68.6 & 7.2 & 2550.0 & 1790.0 & -9.2 \\
\hline 49 & V.Duraiswamipuram & $77^{\circ} 47^{\prime} 56^{\prime \prime}$ & $9^{\circ} 20^{\prime} 57^{\prime \prime}$ & 172.0 & 122.4 & 90.7 & 5.5 & 401.3 & 463.6 & 6.7 & 26.1 & 66.7 & 7.3 & 1320.0 & 936.0 & -7.5 \\
\hline 50 & Elayirampannai & $77^{\circ} 48^{\prime} 59^{\prime \prime}$ & $9^{\circ} 16^{\prime} 21^{\prime \prime}$ & 100.0 & 50.4 & 10.8 & 3.7 & 70.9 & 329.4 & 6.2 & 25.3 & 44.8 & 7.4 & 483.0 & 345.0 & -9.1 \\
\hline 51 & Varaganur & $77^{\circ} 43^{\prime} 31^{\prime \prime}$ & $9^{\circ} 16^{\prime} 26^{\prime \prime}$ & 892.0 & 345.6 & 481.8 & 296.4 & 2466.2 & 824.6 & 6.2 & 22.1 & 68.6 & 7.0 & 5200.0 & 3680.0 & -9.7 \\
\hline 52 & Muthu swamipuram & $77^{\circ} 44^{\prime} 23^{\prime \prime}$ & $9^{\circ} 20^{\prime} 40^{\prime \prime}$ & 72.0 & 144.0 & 57.4 & 4.3 & 224.1 & 573.4 & 7.6 & 30.4 & 15.3 & 7.6 & 984.0 & 694.0 & -4.6 \\
\hline 53 & Idiyankulam & $77^{\circ} 43^{\prime} 12^{\prime \prime}$ & $9^{\circ} 25^{\prime} 21^{\prime \prime}$ & 100.0 & 96.0 & 48.3 & 3.7 & 141.8 & 488.0 & 6.2 & 22.4 & 65.1 & 7.2 & 830.0 & 580.0 & -9.1 \\
\hline 54 & unamnatti & ${ }^{\circ} 42 ' 31 "$ & $9^{\circ} 31^{\prime} 18^{\prime \prime}$ & 128.0 & 43.2 & 11.7 & 3.7 & 90.9 & 353.8 & 6.1 & 19.4 & 57.0 & 8.0 & 402.0 & 284.0 & -8.4 \\
\hline 55 & Nathampatti & $77^{\circ} 45^{\prime} 5^{\prime \prime}$ & $9^{\circ} 35^{\prime} 45^{\prime \prime}$ & 60.0 & 76.8 & 87.7 & 3.5 & 124.1 & 658.8 & 6.4 & 24.3 & 50.8 & 8.0 & 823.0 & 587.0 & 6.0 \\
\hline 56 & Tailapuram & $77^{\circ} 46^{\prime} 37^{\prime \prime}$ & $9^{\circ} 39^{\prime} 39^{\prime \prime}$ & 72.0 & 156.0 & 47.3 & 3.1 & 268.2 & 451.4 & 6.1 & 26.4 & 47.1 & 8.0 & 816.0 & 578.0 & -8.8 \\
\hline 57 & Mavuoothu & $77^{\circ} 40^{\prime} 27^{\prime \prime}$ & $9^{\circ} 40^{\prime} 43^{\prime \prime}$ & 36.0 & 40.8 & 10.7 & 3.6 & 53.2 & 256.2 & 6.3 & 25.2 & 45.8 & 7.0 & 295.0 & 207.0 & 5.5 \\
\hline 58 & Sundarapandiam & $77^{\circ} 40^{\prime} 35^{\prime \prime}$ & $9^{\circ} 36^{\prime} 41^{\prime \prime}$ & 64.0 & 122.4 & 36.3 & 3.5 & 53.2 & 622.2 & 6.2 & 25.0 & 38.3 & 7.5 & 784.0 & 556.0 & -9.6 \\
\hline 59 & Srivilliputtur & $77^{\circ} 37^{\prime} 43^{\prime \prime}$ & $9^{\circ} 30^{\prime} 30^{\prime \prime}$ & 160.0 & 76.8 & 50.3 & 27.3 & 260.4 & 402.6 & 6.2 & 30.3 & 45.7 & 7.6 & 1308.0 & 928.0 & -7.8 \\
\hline 60 & Pazhaya chennelkulam & $77^{\circ} 38^{\prime} 3^{\prime \prime}$ & $9^{\circ} 25^{\prime} 56^{\prime \prime}$ & 76.0 & 52.8 & 10.7 & 3.3 & 70.9 & 305.0 & 6.8 & 29.3 & 42.9 & 7.6 & 417.0 & 293.0 & -5.5 \\
\hline 61 & Sivalingapuram & $77^{\circ} 38^{\prime} 19^{\prime \prime}$ & $9^{\circ} 20^{\prime} 34^{\prime \prime}$ & 260.0 & 93.6 & 153.4 & 137.8 & 549.5 & 658.8 & 6.5 & 33.8 & 47.9 & 7.0 & 1903.0 & 950.0 & -6.4 \\
\hline 62 & Ramarajapuram & $77^{\circ} 38^{\prime} 23^{\prime \prime}$ & $9^{\circ} 17^{\prime} 49^{\prime \prime}$ & 72.0 & 32.0 & 25.1 & 3.5 & 88.6 & 353.8 & 6.3 & 29.2 & 48.4 & 7.5 & 504.0 & 356.0 & 10.1 \\
\hline 63 & Vijayarengapuram & $77^{\circ} 35^{\prime} 7^{\prime \prime}$ & $9^{\circ} 18^{\prime} 29^{\prime \prime}$ & 404.0 & 9.6 & 71.4 & 3.5 & 439.5 & 475.8 & 6.4 & 31.4 & 46.0 & 7.1 & 1120.0 & 780.0 & -6.9 \\
\hline 64 & Asilapuram & $77^{\circ} 33^{\prime} 53^{\prime \prime}$ & $9^{\circ} 21^{\prime} 34^{\prime \prime}$ & 236.0 & 4.8 & 184.2 & 6.7 & 514.0 & 512.4 & 6.2 & 34.5 & 31.3 & 7.6 & 1616.0 & 1120.0 & 7.8 \\
\hline 65 & Mill krishanapuram & $77^{\circ} 34^{\prime} 4^{\prime \prime}$ & $9^{\circ} 26^{\prime} 13^{\prime \prime}$ & 304.0 & 50.4 & 210.6 & 6.9 & 904.0 & 549.0 & 6.3 & 35.0 & 47.9 & 7.7 & 3150.0 & 2230.0 & 10.4 \\
\hline 66 & Rajaplayam & $77^{\circ} 33^{\prime} 36^{\prime \prime}$ & $9^{\circ} 27^{\prime} 39^{\prime \prime}$ & 188.0 & 67.6 & 155.0 & 8.2 & 531.8 & 671.0 & 6.5 & 29.2 & 21.2 & 7.4 & 1668.0 & 1340.0 & 9.9 \\
\hline 67 & Mamsapuram & $77^{\circ} 35^{\prime} 19^{\prime \prime}$ & $9^{\circ} 29^{\prime} 45^{\prime \prime}$ & 88.0 & 61.2 & 92.9 & 3.2 & 177.3 & 585.6 & 6.3 & 26.4 & 41.1 & 7.5 & 934.0 & 661.0 & 6.0 \\
\hline 68 & Kansapuram & $77^{\circ} 36^{\prime} 9^{\prime \prime}$ & $9^{\circ} 37^{\prime} 38^{\prime \prime}$ & 136.0 & 41.2 & 172.9 & 2.9 & 336.8 & 671.0 & 6.6 & 28.8 & 42.6 & 7.2 & 1656.0 & 1170.0 & 8.9 \\
\hline 69 & Nedungulam & $77^{\circ} 35^{\prime} 54^{\prime \prime}$ & $9^{\circ} 39^{\prime} 18^{\prime \prime}$ & 152.0 & 57.6 & 46.6 & 3.1 & 177.3 & 622.2 & 6.6 & 26.5 & 54.2 & 7.1 & 1008.0 & 708.0 & 4.8 \\
\hline 70 & Nallamangalam & $77^{\circ} 28^{\prime} 1^{\prime \prime}$ & $9^{\circ} 23^{\prime} 3^{\prime \prime}$ & 136.0 & 65.6 & 138.1 & 3.4 & 336.8 & 744.2 & 6.8 & 28.7 & 50.4 & 7.0 & 1445.0 & 1010.0 & 10.2 \\
\hline
\end{tabular}




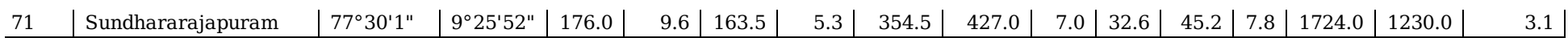

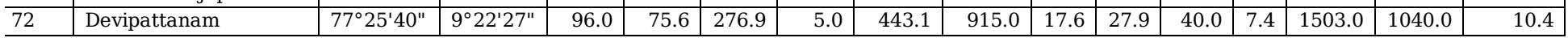

Table. 3 Maximum, minimum and average values for the analytical results of groundwater samples.

\begin{tabular}{|c|c|c|c|c|c|}
\hline Parameters & Max & Min & Avg & WHO 2014 & \% of samples > WHO 2014 \\
\hline $\mathrm{Ca}(\mathrm{mg} / \mathrm{L})$ & 892.0 & 20.0 & 153.9 & 200.0 & $22 \%$ \\
\hline $\mathrm{Mg}(\mathrm{mg} / \mathrm{L})$ & 450.4 & 4.8 & 90.7 & 150.0 & $11 \%$ \\
\hline $\mathrm{Na}(\mathrm{mg} / \mathrm{L})$ & 944.4 & 9.1 & 151.6 & 200.0 & $24 \%$ \\
\hline $\mathrm{K}(\mathrm{mg} / \mathrm{L})$ & 296.4 & 2.8 & 16.6 & 10.0 & $17 \%$ \\
\hline $\mathrm{Cl}(\mathrm{mg} / \mathrm{L})$ & 2980.2 & 53.2 & 441.8 & 600.0 & $19 \%$ \\
\hline $\mathrm{HCO}_{3}(\mathrm{mg} / \mathrm{L})$ & 1198.0 & 134.2 & 539.7 & 500.0 & $35 \%$ \\
\hline $\mathrm{PO}_{4}(\mathrm{mg} / \mathrm{L})$ & 22.7 & 5.5 & 7.1 & $\mathrm{NG}$ & \\
\hline $\mathrm{SO}_{4}(\mathrm{mg} / \mathrm{L})$ & 35.0 & 3.7 & 19.5 & 400.0 & Nil \\
\hline $\mathrm{SiO}_{2}(\mathrm{mg} / \mathrm{L})$ & 84.2 & 9.9 & 49.6 & $\mathrm{NG}$ & \\
\hline $\mathrm{pH}$ & 8.4 & 6.8 & 7.5 & $6.5-8.5$ & $36 \%$ \\
\hline $\mathrm{EC} \mu \mathrm{s} / \mathrm{cm}$ & 5870.0 & 273.0 & 1593.0 & 1500.0 & $21 \%$ \\
\hline $\mathrm{TDS}(\mathrm{mg} / \mathrm{L})$ & 4160.0 & 194.0 & 1136.0 & 1500.0 & \\
\hline
\end{tabular}

Table. 4 Suitability of groundwater for drinking and irrigation (Results from CHIDAM software, Chidambaram et al 2020)

\begin{tabular}{|c|c|c|c|c|c|c|c|}
\hline Category & Range & $\begin{array}{l}\text { Number of } \\
\text { Samples }\end{array}$ & $\begin{array}{l}\text { Percentage of } \\
\text { Samples }\end{array}$ & Category & Range & $\begin{array}{l}\text { Number of } \\
\text { Samples }\end{array}$ & $\begin{array}{l}\text { Percentage of } \\
\text { Samples }\end{array}$ \\
\hline \multicolumn{4}{|c|}{$\mathrm{Na} \%$ (Wilcox, 1955) } & \multicolumn{4}{|c|}{ Indices of Base Exchange (IBE) Schoeller (1965) } \\
\hline Excellent & $0-20$ & 30 & $42 \%$ & $\begin{array}{l}\text { Exchange between } \mathrm{Na} \text { and } \mathrm{K} \text { in rock with } \mathrm{Mg} \text { or } \mathrm{Ca} \\
\text { in groundwater }\end{array}$ & & 17 & $24 \%$ \\
\hline Good & $20-40$ & 27 & $38 \%$ & $\begin{array}{l}\text { Exchange between } \mathrm{Na} \text { and } \mathrm{K} \text { in groundwater with } \\
\mathrm{Mg} \text { or Ca in rock }\end{array}$ & & 55 & $76 \%$ \\
\hline Permissible & $40-60$ & 12 & $17 \%$ & \multicolumn{4}{|c|}{$\begin{array}{ll}\text { TDS Classification(USSl 1954) }\end{array}$} \\
\hline Doubtful & $60-80$ & 2 & $3 \%$ & $<200$ & & 1 & $1 \%$ \\
\hline Unsuitable & $>80$ & 1 & $1 \%$ & $200-500$ & & 15 & $21 \%$ \\
\hline \multicolumn{4}{|c|}{$\mathrm{Na}$ \% (Eaton,1950) } & $500-1500$ & & 39 & $54 \%$ \\
\hline Safe & $<60$ & 69 & $96 \%$ & $1500-3000$ & & 11 & $15 \%$ \\
\hline Unsafe & $>60$ & 3 & $4 \%$ & $>3000$ & & 6 & $8 \%$ \\
\hline \multicolumn{4}{|c|}{ Kelly Ratio,(Kelly,1946) } & \multicolumn{4}{|c|}{ Chloride Classification (Stufzand 1989c) } \\
\hline Safe & $<1$ & 66 & $92 \%$ & Extremely Fresh & $<0.141$ & 0 & \\
\hline Unsafe & $>1$ & 6 & $8 \%$ & Very Fresh & $0.141-0.846$ & 0 & \\
\hline \multicolumn{4}{|c|}{ Magnesium Adsorption Ratio (Lloyd\& Heathcoat (1985) } & Fresh & $0.846-4.231$ & 28 & $39 \%$ \\
\hline Safe & $<50$ & 30 & $42 \%$ & Fresh Brackish & $4.231-8.462$ & 12 & $17 \%$ \\
\hline Unsafe & $>50$ & 42 & $58 \%$ & Brackish & $\begin{array}{r}8.462- \\
28.206\end{array}$ & 26 & $36 \%$ \\
\hline \multicolumn{3}{|c|}{$\begin{array}{l}\text { Sodium Adsorption Ratio (Richards } \\
\text { 1954) }\end{array}$} & & Brackish salt & $\begin{array}{r}28.206- \\
282.064 \\
\end{array}$ & 6 & $8 \%$ \\
\hline Excellent & $0-10$ & 69 & $96 \%$ & Salt & $\begin{array}{r}282.064- \\
564.127\end{array}$ & 0 & \\
\hline Good & $10-18$ & 3 & $4 \%$ & Hyperhaline & $>564.127$ & 0 & \\
\hline Fair & $18-26$ & 0 & & \multicolumn{4}{|c|}{ CATION FACIES } \\
\hline Poor & $>26$ & 0 & & Calcium-Magnesium Facies & & 29 & $40 \%$ \\
\hline \multicolumn{4}{|c|}{ Residual Sodium Carbonate (Richards,1954) } & Calcium-Sodium Facies & & 43 & $60 \%$ \\
\hline Good & $<1.25$ & 57 & $79 \%$ & Sodium-Calcium Facies & & 0 & \\
\hline Medium & $\begin{array}{r}1.25- \\
2.5\end{array}$ & 7 & $10 \%$ & Sodium Facies & & 0 & \\
\hline Bad & $>2.5$ & 8 & $11 \%$ & & & & \\
\hline \multicolumn{4}{|c|}{ Electrical Conductivity (Wilcox,1955) } & \multicolumn{4}{|c|}{ ANION FACIES } \\
\hline Excellent & $<250$ & 0 & & Bicarbonte Facies & & 0 & \\
\hline Good & $\begin{array}{r}250- \\
750\end{array}$ & 18 & $25 \%$ & Bicarbonate-Chloride-Sulfate Facies & & 0 & \\
\hline Permissible & $\begin{array}{r}750- \\
2250\end{array}$ & 39 & $54 \%$ & Chloride-Sulfate-Bicarbonate Facies & & 66 & $92 \%$ \\
\hline Doubtful & $\begin{array}{r}2250- \\
5000\end{array}$ & 12 & $17 \%$ & Chloride Facies & & 6 & $8 \%$ \\
\hline Unsuitable & $>5000$ & 3 & $4 \%$ & & & & \\
\hline \multicolumn{8}{|c|}{ Sawyer and McCarty Hardness } \\
\hline Soft & $<75$ & 0 & & & & & \\
\hline $\begin{array}{l}\text { Slightly } \\
\text { Hard }\end{array}$ & $75-150$ & 0 & & & & & \\
\hline $\begin{array}{l}\text { Moderately } \\
\text { Hard }\end{array}$ & $\begin{array}{r}150- \\
300\end{array}$ & 11 & $15 \%$ & & & & \\
\hline Very Hard & $>300$ & 61 & $85 \%$ & & & & \\
\hline
\end{tabular}

Page $12 / 23$ 
Table. 5 Correlation matrix for the variable in groundwater

\begin{tabular}{|c|c|c|c|c|c|c|c|c|c|c|c|c|}
\hline Parameters & $\mathrm{Ca}$ & $\mathrm{Mg}$ & $\mathrm{Na}$ & $\mathbf{K}$ & $\mathrm{Cl}$ & $\mathrm{HCO}_{3}$ & $\mathrm{PO}_{4}$ & $\mathrm{SO}_{4}$ & $\mathrm{H}_{4} \mathrm{SiO}_{4}$ & $\mathrm{pH}$ & EC & TDS \\
\hline $\mathrm{Ca}$ & 1.00 & & & & & & & & & & & \\
\hline $\mathrm{Mg}$ & 0.67 & 1.00 & & & & & & & & & & \\
\hline $\mathrm{Na}$ & 0.46 & 0.63 & 1.00 & & & & & & & & & \\
\hline $\mathrm{K}$ & 0.59 & 0.40 & 0.21 & 1.00 & & & & & & & & \\
\hline $\mathrm{Cl}$ & 0.87 & 0.85 & 0.78 & 0.49 & 1.00 & & & & & & & \\
\hline $\mathrm{HCO}_{3}$ & 0.14 & 0.39 & 0.74 & 0.21 & 0.41 & 1.00 & & & & & & \\
\hline $\mathrm{PO}_{4}$ & 0.03 & 0.05 & 0.06 & 0.12 & 0.03 & 0.21 & 1.00 & & & & & \\
\hline $\mathrm{SO}_{4}$ & 0.15 & -0.01 & 0.00 & 0.11 & 0.02 & 0.14 & 0.09 & 1.00 & & & & \\
\hline $\mathrm{H}_{4} \mathrm{SiO}_{4}$ & 0.12 & 0.15 & 0.27 & 0.18 & 0.17 & 0.17 & 0.15 & 0.01 & 1.00 & & & \\
\hline $\mathrm{pH}$ & -0.47 & -0.23 & -0.07 & -0.23 & -0.32 & 0.004 & -0.09 & -0.21 & -0.21 & 1.00 & & \\
\hline EC & 0.65 & 0.72 & 0.91 & 0.36 & 0.88 & 0.65 & 0.06 & 0.02 & 0.29 & -0.20 & 1.00 & \\
\hline TDS & 0.63 & 0.72 & 0.91 & 0.34 & 0.87 & 0.66 & 0.05 & 0.00 & 0.28 & -0.18 & 0.99 & 1.00 \\
\hline
\end{tabular}

Table. 6 Factor analysis for the chemical composition of Groundwater.

\begin{tabular}{|l|r|r|r|}
\hline Parameter & Factor I & Factor II & Factor III \\
\hline $\mathrm{Ca}$ & 0.44 & 0.84 & -0.05 \\
\hline $\mathrm{Mg}$ & 0.69 & 0.49 & -0.09 \\
\hline $\mathrm{Na}$ & 0.96 & 0.06 & 0.09 \\
\hline $\mathrm{K}$ & 0.22 & 0.64 & 0.15 \\
\hline $\mathrm{Cl}$ & 0.77 & 0.59 & -0.09 \\
\hline $\mathrm{HCO}_{3}$ & 0.77 & -0.18 & 0.38 \\
\hline $\mathrm{PO}_{4}$ & 0.05 & -0.03 & 0.73 \\
\hline $\mathrm{SO}_{4}$ & -0.13 & 0.26 & 0.54 \\
\hline $\mathrm{H}_{4} \mathrm{SiO}_{4}$ & 0.24 & 0.10 & 0.47 \\
\hline $\mathrm{pH}$ & 0.06 & -0.71 & -0.28 \\
\hline EC & 0.93 & 0.30 & 0.06 \\
\hline TDS & 0.93 & 0.27 & 0.05 \\
\hline Total Variance & 39.00 & 21.00 & 11.00 \\
\hline
\end{tabular}

\section{Figures}




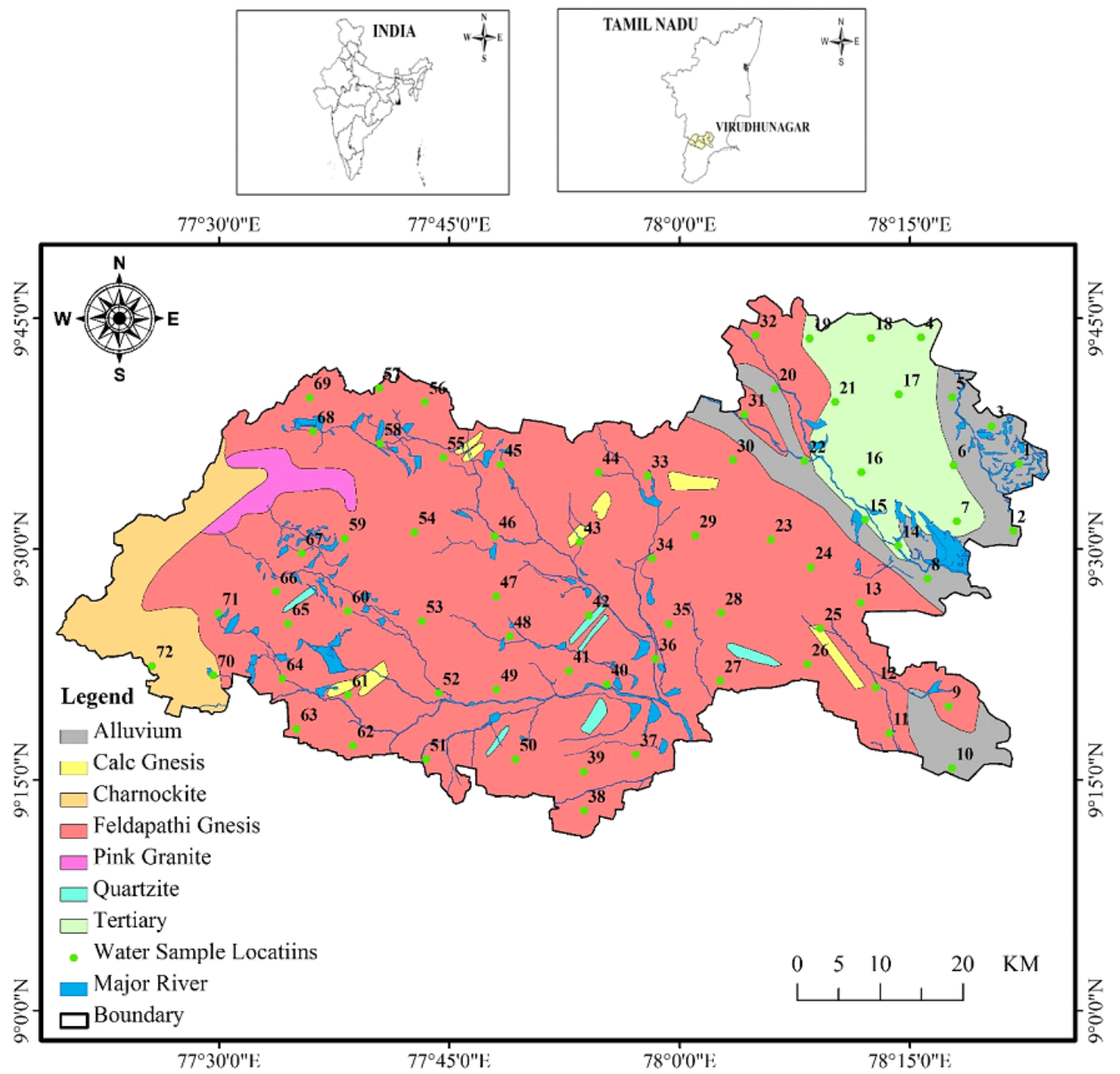

\section{Figure 1}

Lithology, Drainage and Groundwater water sampling locations of the study. Note: The designations employed and the presentation of the material on this map do not imply the expression of any opinion whatsoever on the part of Research Square concerning the legal status of any country, territory, city or area or of its authorities, or concerning the delimitation of its frontiers or boundaries. This map has been provided by the authors. 


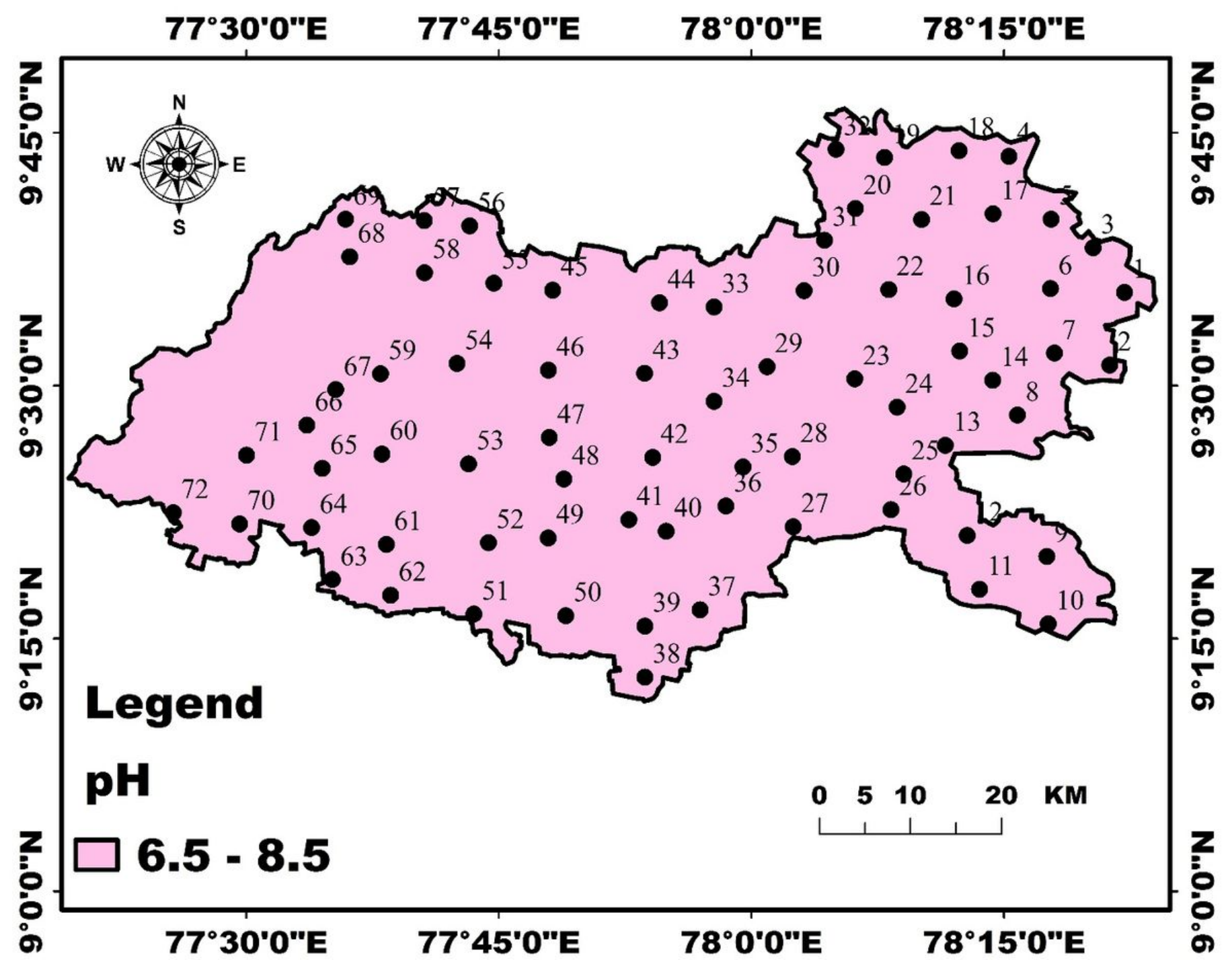

Figure 2

Spatial distribution of $\mathrm{pH}$ in groundwater samples 


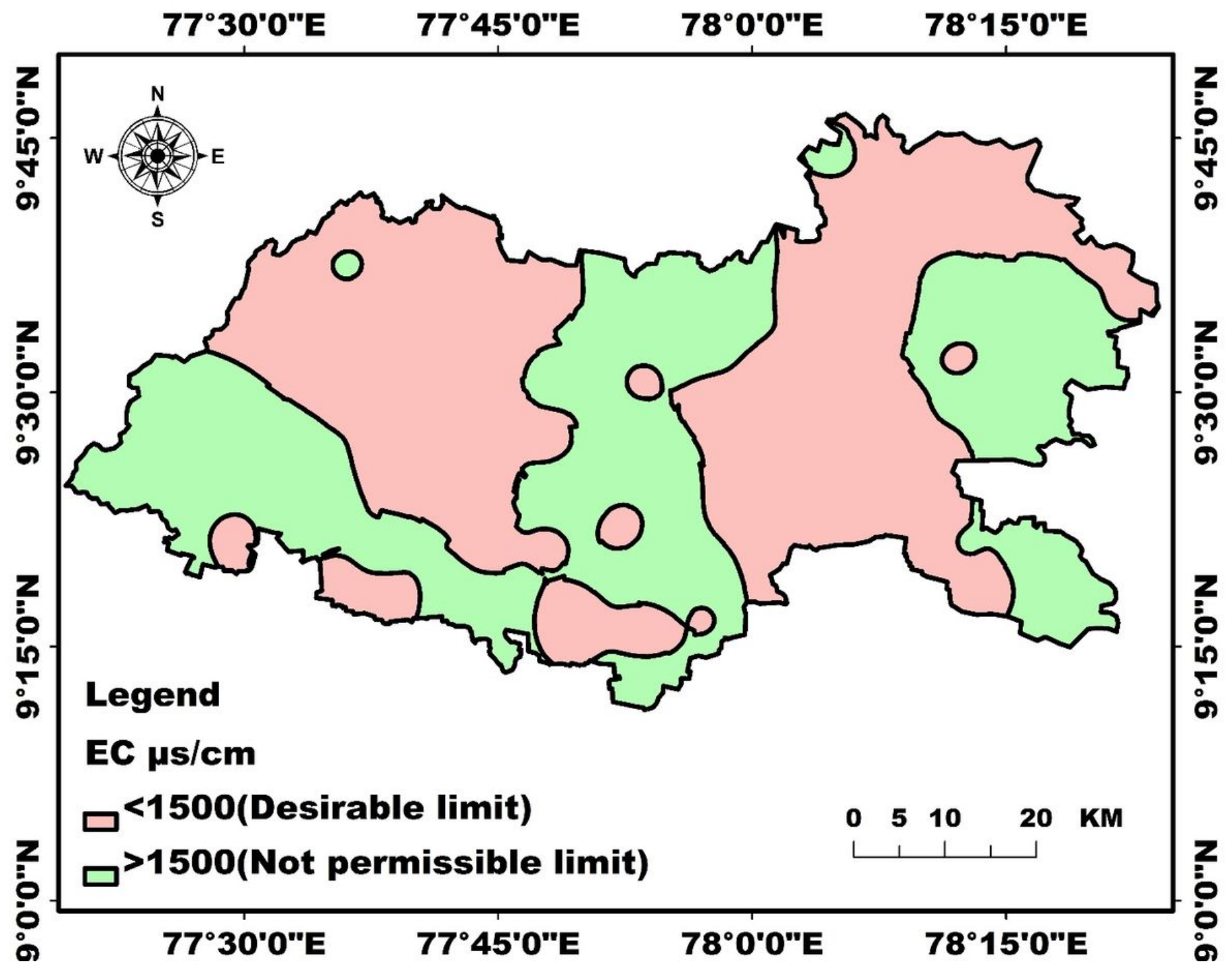

Figure 3

Spatial distribution of EC $(\mu \mathrm{S} / \mathrm{cm})$ in groundwater samples
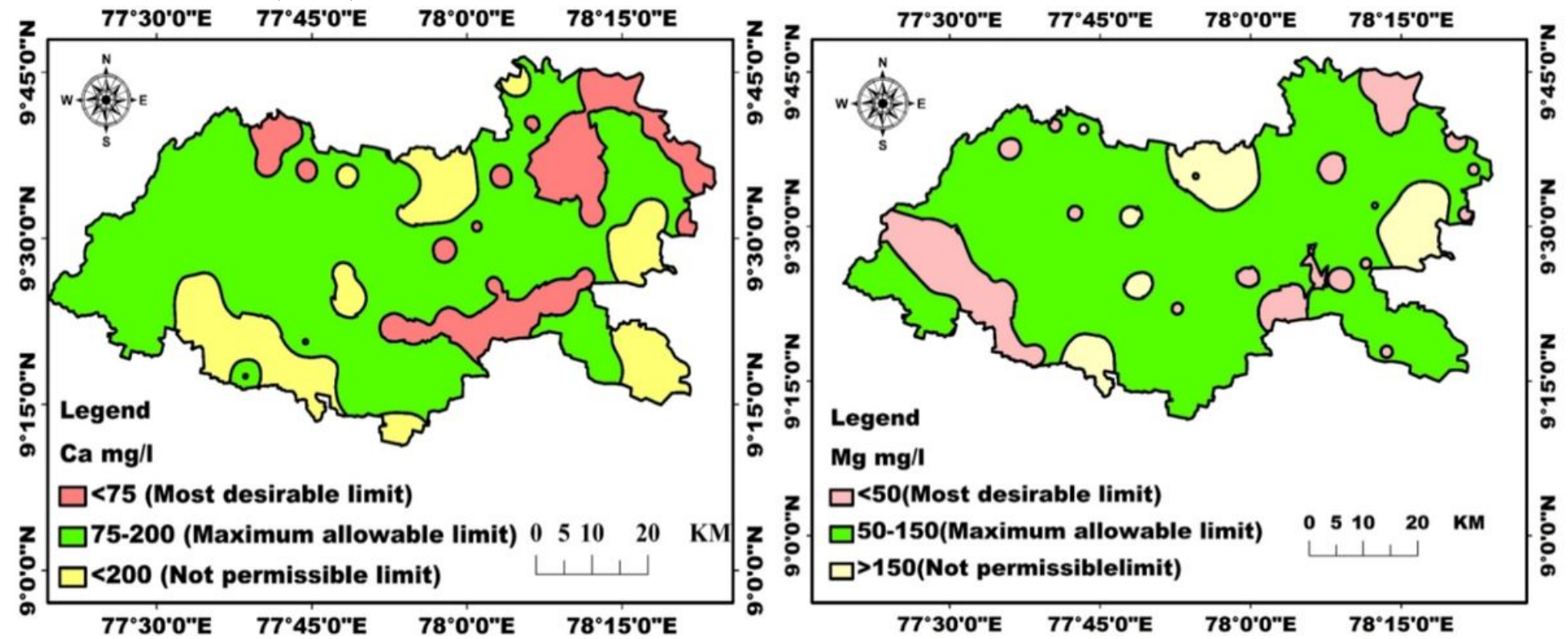

Figure 4 

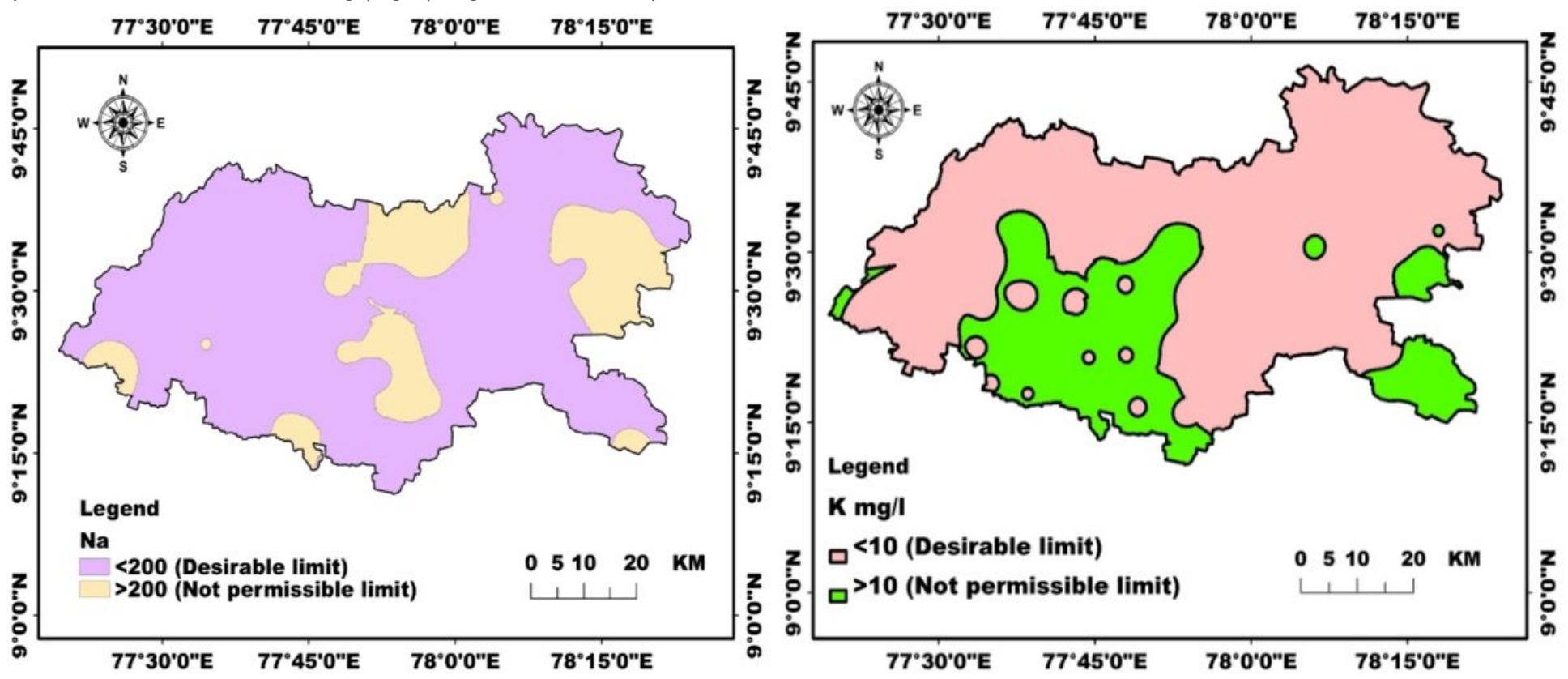

Figure 5

Spatial distribution of $\mathrm{Na}$ and $\mathrm{K}(\mathrm{mg} / \mathrm{L})$ in groundwater samples

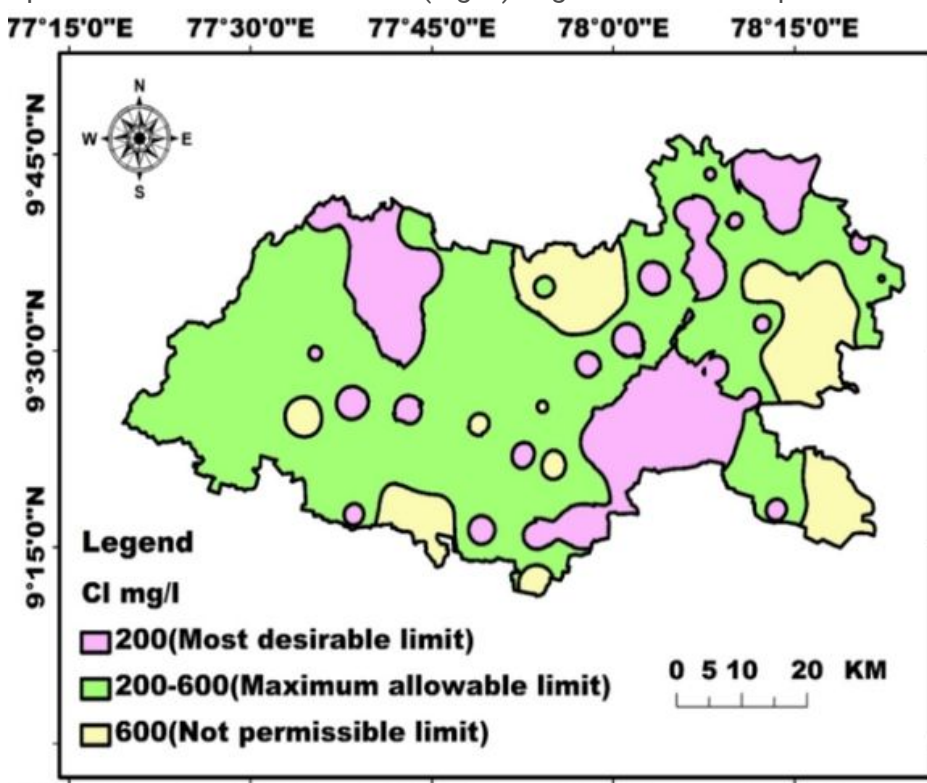

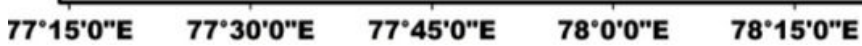

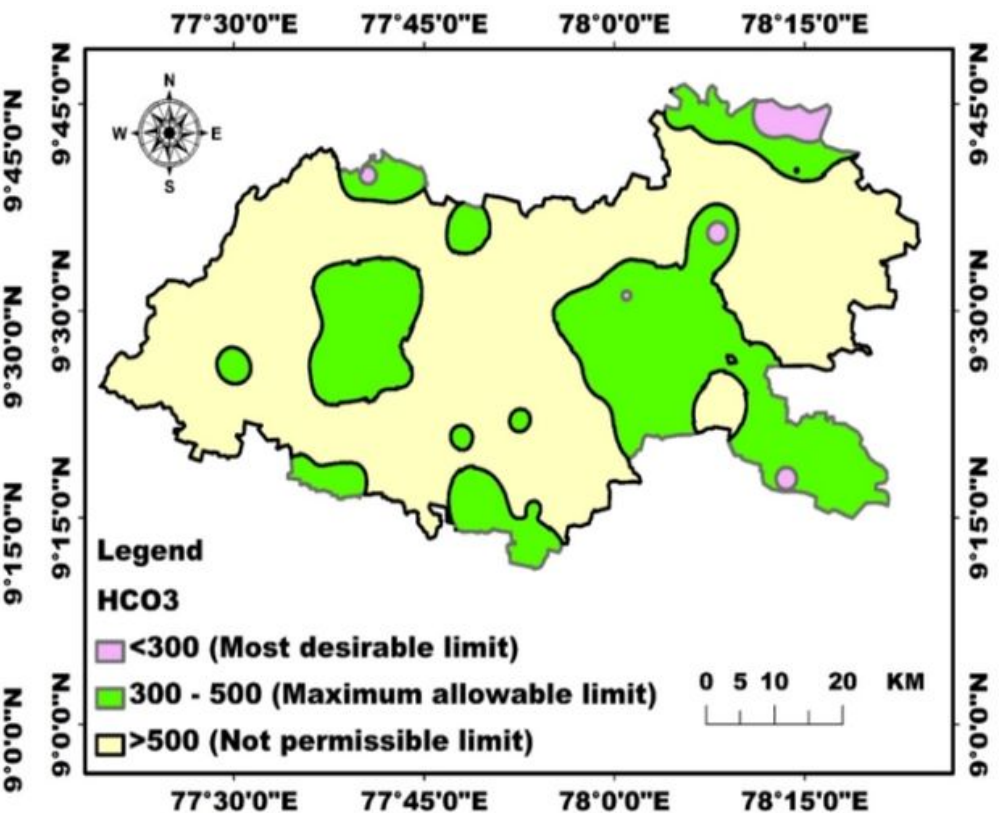

Figure 6

Spatial distribution of $\mathrm{Cl}$ and $\mathrm{HCO} 3(\mathrm{mg} / \mathrm{L})$ in groundwater samples 


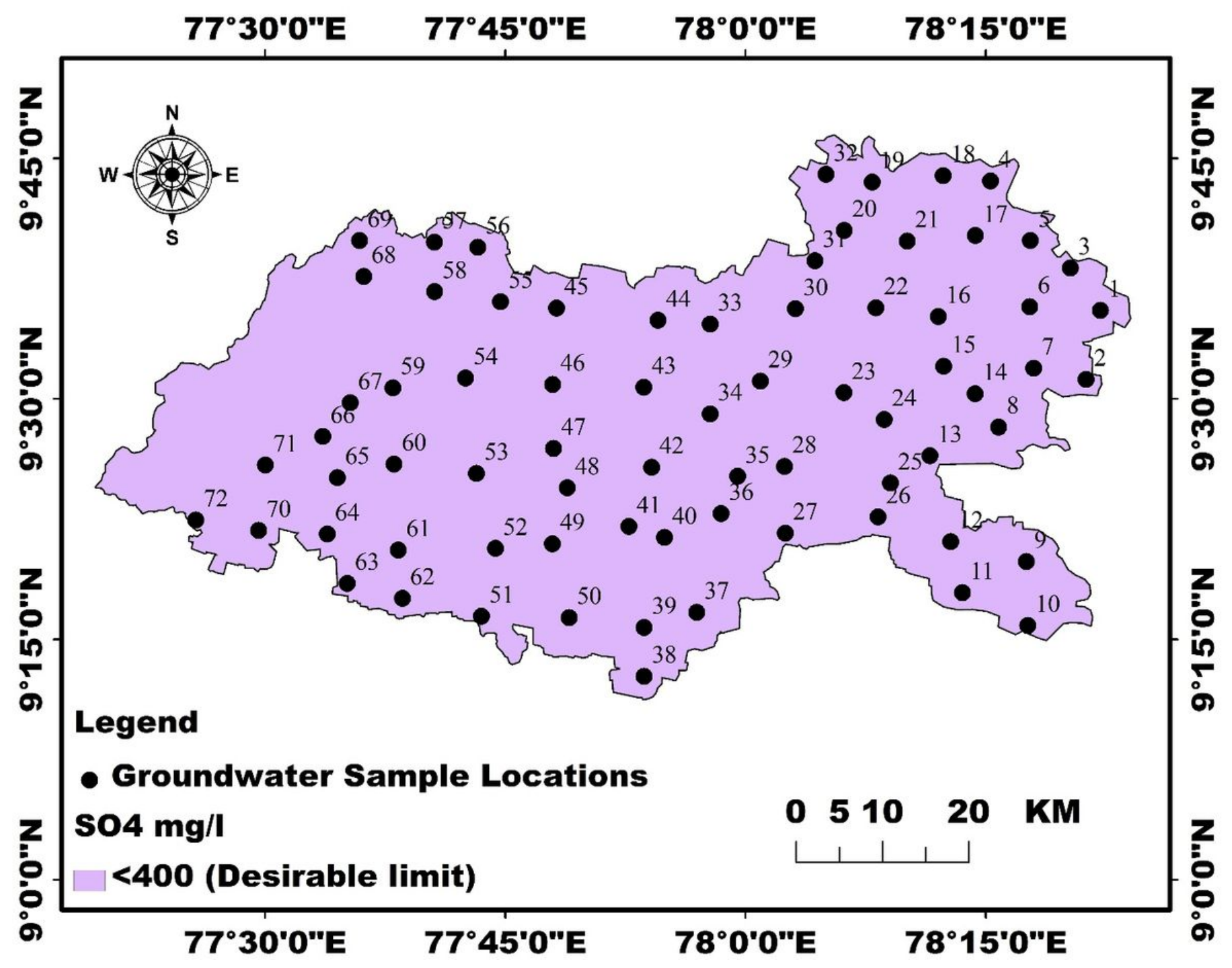

Figure 7

Spatial distribution of SO4 $(\mathrm{mg} / \mathrm{L})$ in groundwater samples 


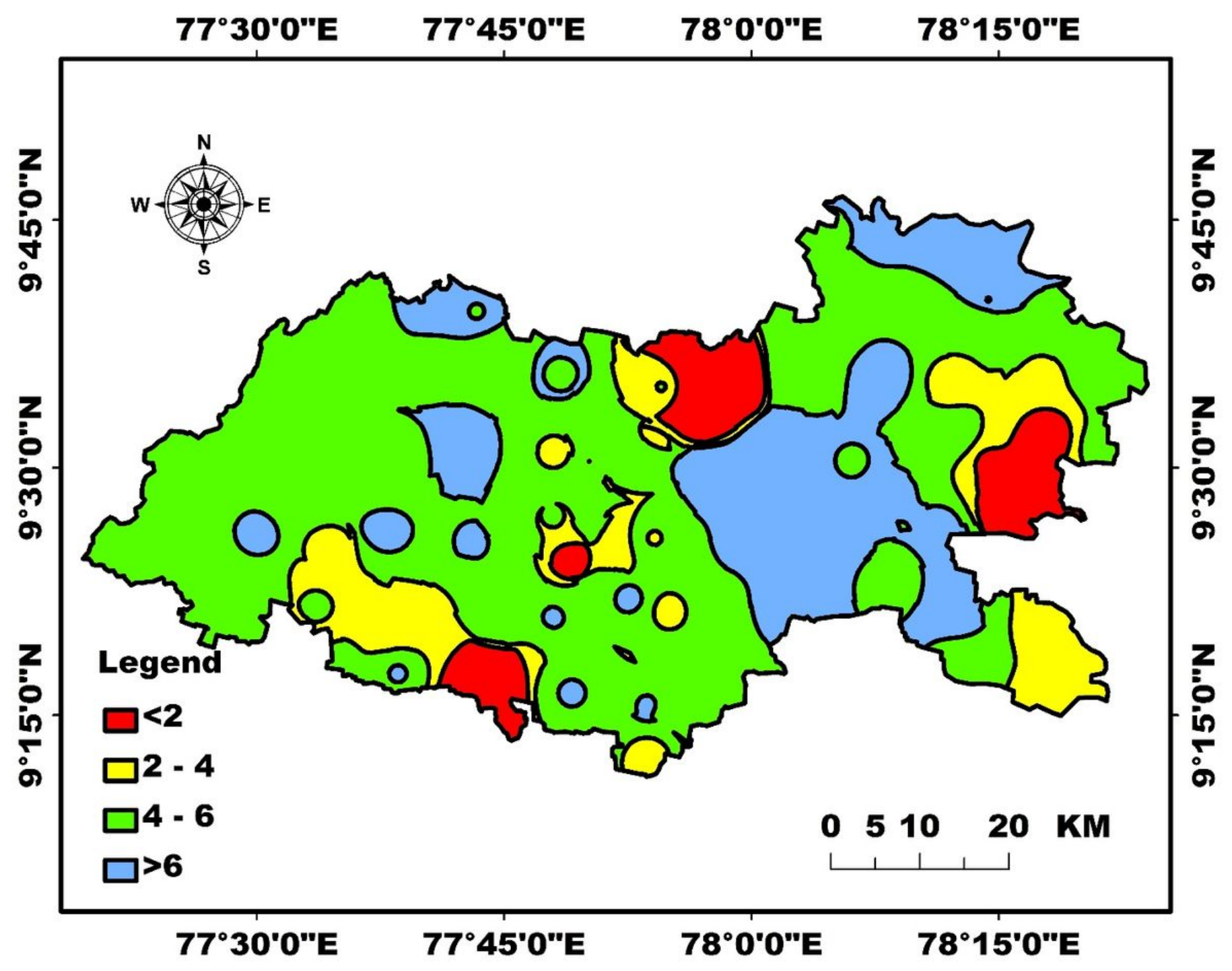

Figure 8

Suitability for drinking water quality map for the groundwater sample 


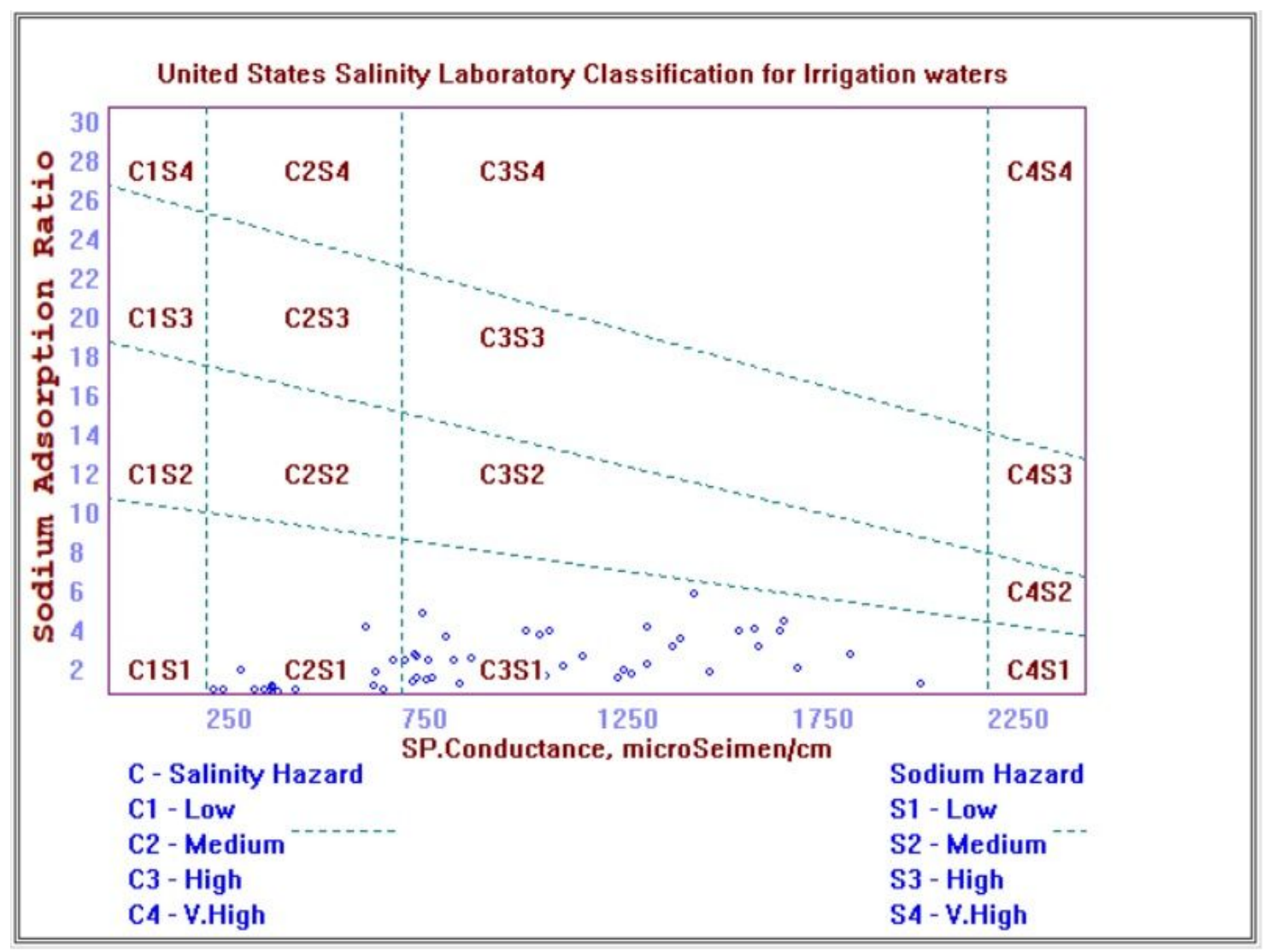

Figure 9

Classification of ground samples in relation to salinity hazard and sodim hazard. 


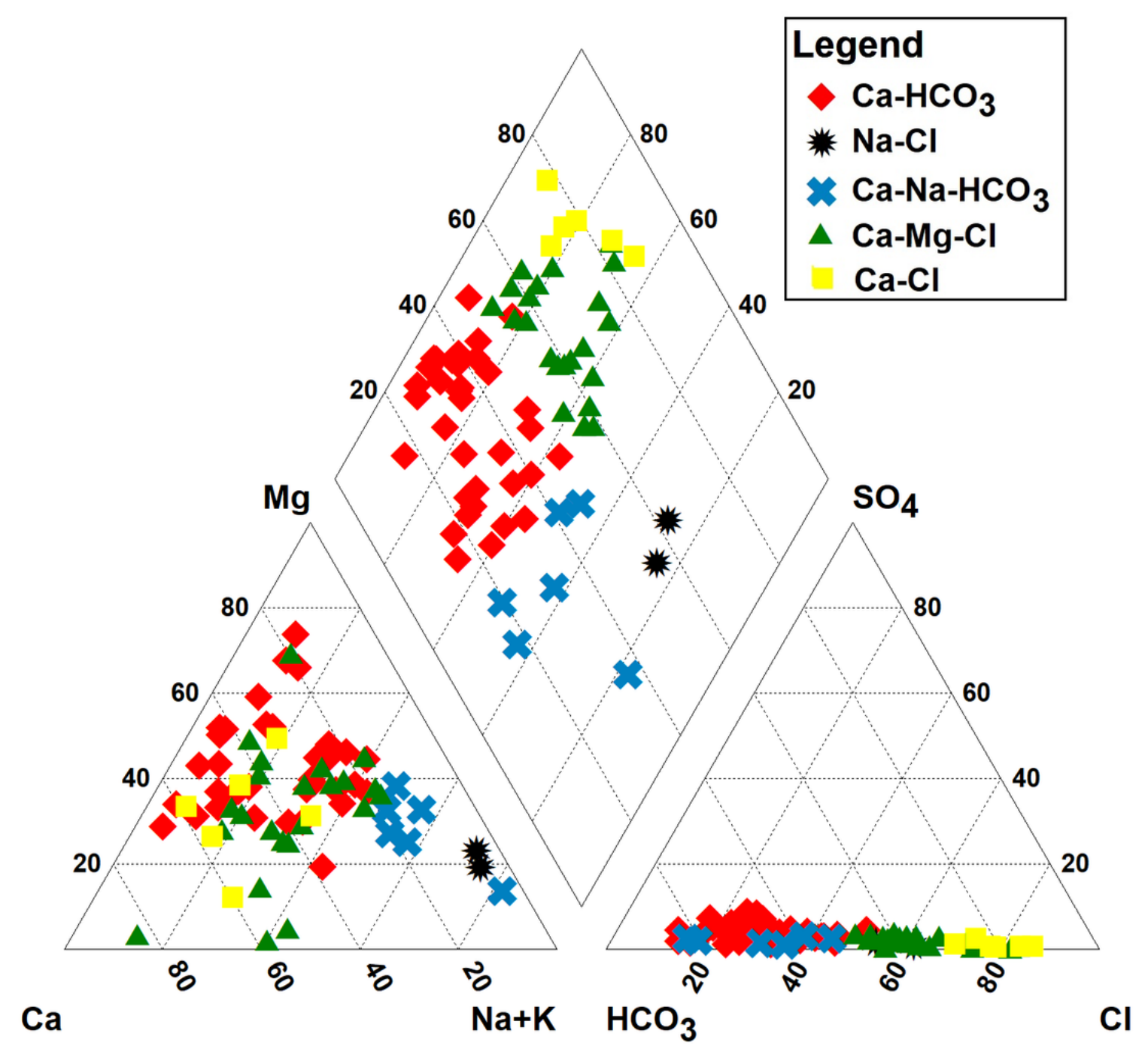

Figure 10

Piper facies diagram for groundwater samples 


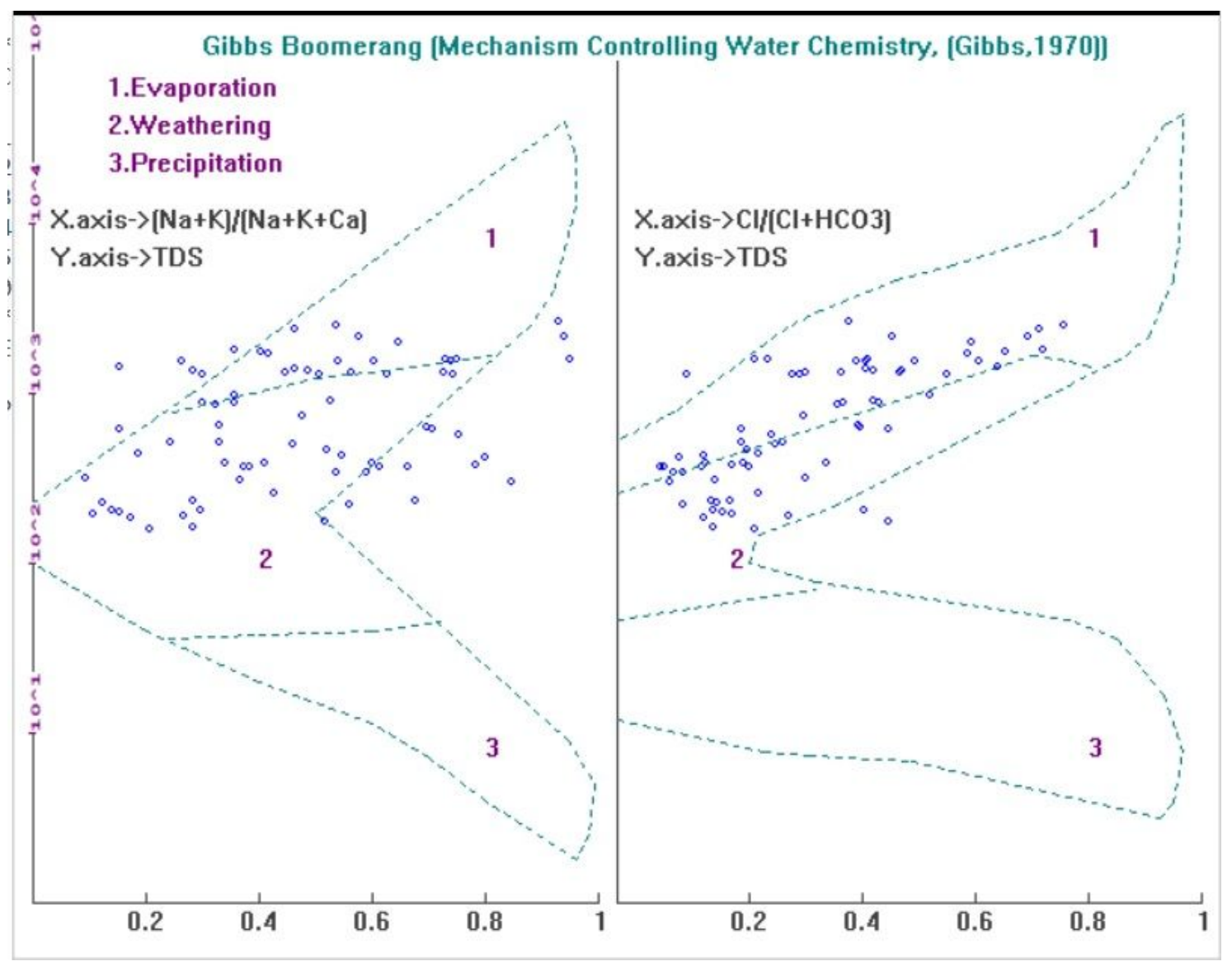

Figure 11

Gibbs plot to identify the mechanism of groundwater chemistry (after Gibbs et al.1970) 


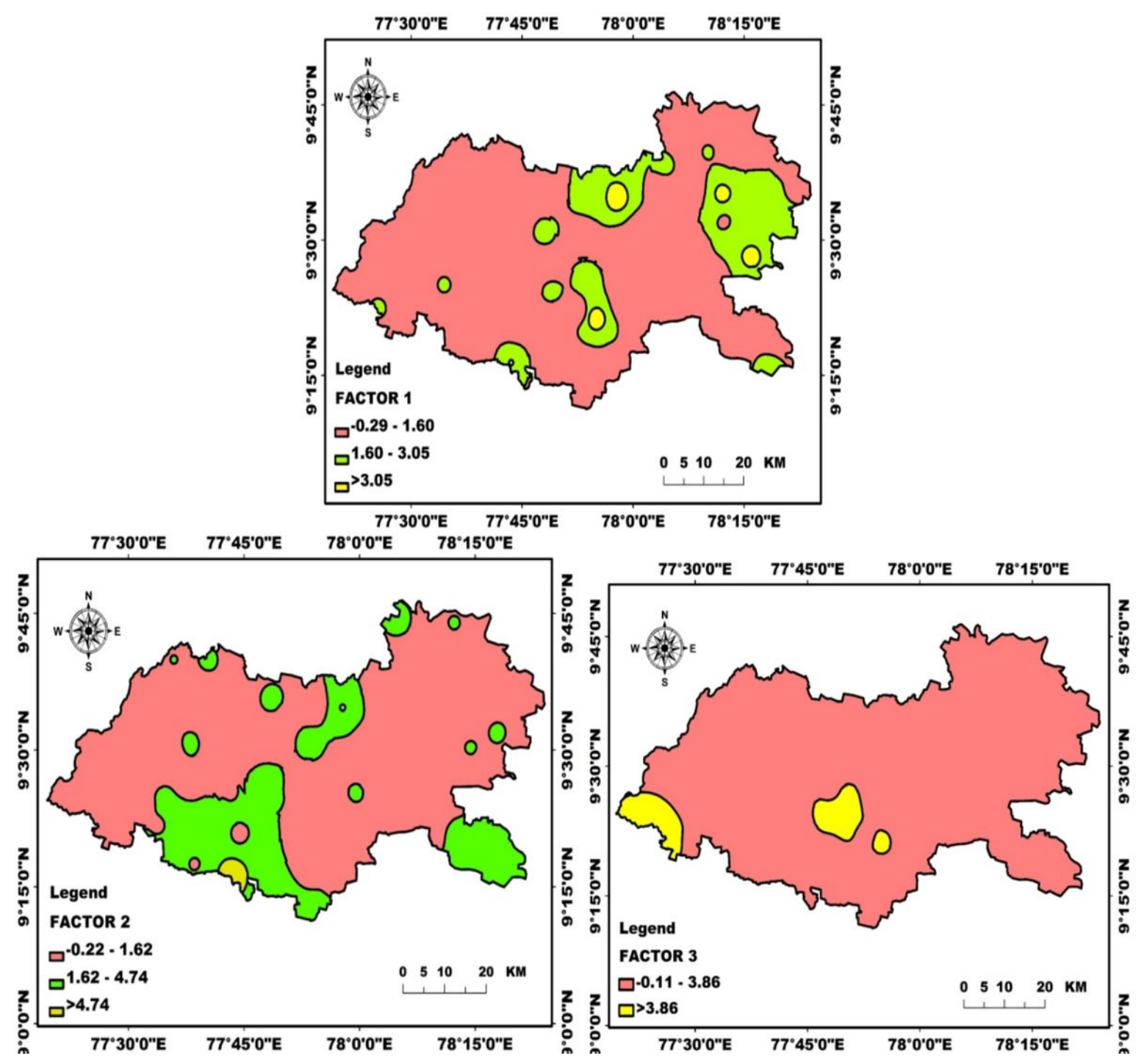

Figure 12

Spatial distribution of factor score for the groundwater samples 